UNIVERSIDADE DE BRASÍLIA

INSTITUTO DE HUMANIDADES

DEPARTAMENTO DE SERVIÇO SOCIAL

TRABALHO DE CONCLUSÃO DE CURSO

\title{
A HISTÓRIA DA CIDADANIA DAS PESSOAS COM DEFICIÊNCIA E O DESENVOLVIMENTO DA SUA ORGANIZAÇÃO COMO MOVIMENTO SOCIAL NO CENÁRIO BRASILEIRO
}

Trabalho de Monografia apresentado pelo aluno Paulo Roberto Costa Beck ao Curso de Serviço Social da Universidade de Brasília - UnB, sob a orientação da Professora: Ms. Patrícia Cristina Pinheiro de Almeida

Brasília, Junho de 2007 


\section{AGRADECIMENTOS}

Agradeço primeiramente a Deus por me permitir estar vivo e, do fundo do meu coração, a minha amada esposa Claudia e ao meu querido filho Antônio que suportaram minhas ausências, entenderam meu silêncio e me apoiaram incansavelmente nesta árdua tarefa de acadêmico. Ao meu pai, Paulo Machado Beck, porque sempre acreditou no meu potencial e apoiou minhas idéias revolucionárias. A minhas irmãs Zilda e Sandra que me ensinaram muito da vida. Ao meu irmão Ernesto que esteve ao meu lado, me acompanhando e oferecendo apoio. A minha irmã Martinha (Mika) que me mostrou um novo caminho através dos livros, e aos meus queridos sobrinhos e sobrinhas.

Ofereço esta monografia para minha amada mãe, Martha Costa Beck, in memoriam, que sonhou e torceu por este dia enquanto viveu. Às minhas filhas queridas, Julia e Carla, in memoriam, que com certeza se orgulhariam muito de seu pai. Aos meus irmãos Helio e Silvio, in memoriam, porque sei que onde estiverem torcem por mim. 


\section{SUMÁRIO}

$\begin{array}{ll}\text { RESUMO } & 04\end{array}$

$\begin{array}{ll}\text { INTRODUÇÃO } & 07\end{array}$

ABORDAGEM TEÓRICO-METODOLÓGICA 12

APRESENTAÇÃO E ANÁLISE DO OBJETO DE ESTUDO 18

CAPÍTULO I. $\quad 18$

1. A Presença dos Humanos com Deficiência sob a Terra 18

2. A História dos Humanos com Deficiência desde as Épocas Remotas da Civilização até a Idade Média $\quad 19$

3. Os Humanos com Deficiência e a Sociedade Industrial. 24

CAPÍTULO II

1. O Desenvolvimento da Cidadania no Ocidente 27

2. A Revolução Francesa e os Direitos do Homem 28

3. A Origem e a Ampliação da Cidadania 29

CAPÍTULO III

1. Os Brasileiros com Deficiência

2. A Cidadania no Brasil $\quad 45$

CONSIDERAÇÕES FINAIS

REFERÊNCIAS BIBLIOGRÁFICAS

$\begin{array}{ll}\text { ANEXOS } & 61\end{array}$ 


\section{RESUMO}

Sempre acreditei que o debate sobre a inclusão social das pessoas com deficiência física, mental, sensorial ou com alguma característica que lhes afaste de padrões compatíveis com os modelos de produção e consumo impostos pela cultura da Sociedade Industrial, capazes de desempenhar os papeis supostamente exigidos das pessoas para o funcionamento equilibrado do sistema, que atinge esses grupos mais vulneráveis socialmente de forma implacável, devia ser travado de um prisma que contemplasse uma visão ontológica desta característica humana, trazendo para o entendimento da problemática uma solução mais instintiva e natural.

Por isso, acredito ser importante resgatar nossa coexistência nos agrupamentos humanos desde os mais remotos tempos, quando formamos instintivamente o edifício da sociedade sob o qual nos apoiamos até os dias atuais, e possamos mensurar a importância deste novo enfoque que julgo importante para o Serviço Social no trato desta problemática, para assegurar a participação destas pessoas no processo de desenvolvimento social.

Desse modo, tratei no primeiro Capítulo deste enfoque, que nos faz viajar aos tempos idos e imaginar como nossos antepassados enfrentavam as agruras e intempéries que os assolavam na luta pela preservação da nossa espécie.

Neste mesmo diapasão de resgate do processo histórico como ferramenta para construção de um novo melhor, revisando e entendendo os processos vividos para deles pinçar os elementos norteadores do percurso que se deve trilhar para superar antigas contradições e estabelecer realmente uma sociedade nova, diversa, pacifica e acolhedora, no Capítulo II julguei fundamental um passeio pelo processo de construção do conceito de cidadania, e pelo processo de construção dos Direitos Humanos inspirado pelos ideais de liberdade, igualdade e fraternidade, para buscarmos na gênese das lutas sociais o fogo capaz de forjar a inspiração que nos leve a construção da nova realidade desejada.

Neste mesmo sentido, resgatar a história das pessoas com deficiência no Brasil, para entender nossa realidade na atualidade, também se mostrou imprescindível para o alcance dos objetivos que pretendi com o presente trabalho de Monografia, realizado a partir das histórias de vida que à luz de uma compreensão mais ampla da realidade, que se dá através da utilização do marco teórico do método histórico e materialista dialético de Karl Marx, permite que a análise do objeto de estudo desta monografia que é a trajetória de construção da cidadania das pessoas com deficiência no Brasil seja melhor aprofundada. 
Este método propiciou na busca de compreensão deste fenômeno o alcance de determinações mais simples, que não aparecem numa primeira observação da realidade e provoca a obtenção de uma rica totalidade de determinações e relações diversas. Pois daí deriva que, para Marx, "O concreto é concreto, porque é a concentração de muitas determinações, isto é, unidade do diverso.” (MARX, in FERNANDES(Org), 1984:.410).

Pretendi ainda, mesmo que minimamente, contribuir com a produção de algum acúmulo de conhecimento nesta área, para que nossa sociedade encontre os caminhos para o alcance de um nível de desenvolvimento social cada vez maior apoiada no conhecimento gerado em nossas instituições de ensino e no seio da sociedade civil, compatível com as conquistas do processo civilizatório, trazendo para a Monografia um testemunho vivo da realidade estudada.

Esta pesquisa documental, que busca recuperar e explicitar a história da deficiência considerou, enfim, as seguintes questões:

- A existência das deficiências/moléstias como característica humana;

- O desenvolvimento do processo de Cidadania e dos Direitos Humanos na Civilização Ocidental;

- O estudo da História da Organização das Pessoas com Deficiência no Brasil;

- Os avanços obtidos pela Organização das Pessoas com Deficiência no Brasil.

Procurei estabelecer ainda uma linha norteadora sobre a trajetória de construção da cidadania das pessoas com deficiência no Brasil para servir como instrumento/ferramenta de apoio para o desenvolvimento de estudos e ações destinadas a este público, bem como de informação e conhecimento acerca do tema, buscando contribuir com a conscientização da sociedade brasileira sobre a magnitude desta questão social, além de explicitar a necessidade do seu enfrentamento com propriedade, dentro do universo dos problemas sociais presentes no cotidiano das comunidades.

Diagnosticar os caminhos para o equacionamento das questões sociais relacionadas a estes contingentes de brasileiros, enfim, está e sempre esteve pelo menos desde os meus dezenove anos quando me tornei paraplégico em acidente de trânsito, na minha pauta cotidiana, e estou seguro de que pela minha própria vivência um trabalho acadêmico de conclusão do curso de Serviço Social voltado para esta área é a melhor contribuição que 
posso dar como retorno à Universidade de Brasília que me acolheu, entendeu e formou, e agora me dá asas para vôos mais seguros. 


\section{INTRODUÇÃO}

Atualmente, mesmo estando explícita a contradição nos modelos de desenvolvimento econômico e social adotados pela humanidade, todas as questões relacionadas à defesa dos Direitos Humanos têm unificado as lutas e permeado as discussões que buscam a formulação e a construção de um modelo de sociedade plural, que acolha e respeite indistintamente a todos.

No caso das pessoas portadoras de deficiência, segundo a Organização Mundial de Saúde - OMS, 10\% (dez por cento) da população mundial, e, segundo o Instituto Brasileiro de Geografia e Estatística - IBGE, de acordo com o censo demográfico de 2002, 14,5\% (catorze e meio) da população brasileira apresenta algum tipo de deficiência, impondo uma abordagem específica e especializada. A questão é séria e ao mesmo tempo complicada e precisa ser entendida como uma questão de Estado.

Quando passei a portar uma paraplegia em decorrência de um acidente de trânsito, aos 19 (dezenove) anos, e comecei a participar do Movimento de Defesa dos Direitos das Pessoas com Deficiência, primeiramente em Brasília e depois no restante do Brasil e até no exterior, pude observar o despreparo da sociedade brasileira e de muitos países que conheci para o enfrentamento adequado das questões sociais relacionadas à inclusão social das pessoas como eu.

O principal aspecto que logo observamos está relacionado à desinformação generalizada sobre o assunto. Até em locais que deveriam deter um mínimo de compreensão da problemática, como hospitais, escolas, transportes e serviços oferecidos ao público de uma forma geral, encontra-se despreparo.

Como conseqüência, identifica-se como elemento indispensável para o alcance de um patamar de cidadania real para estas pessoas a oferta maciça de informações sobre esta questão social e um debate permanente com a sociedade como elemento de suporte para as práticas sociais necessárias.

Como a sociedade brasileira é plural, constatamos que a participação das pessoas com deficiência estava presente em todas as correntes políticas e classes sociais, determinando modelos de compreensão de sociedade diversos para administração e abordagens unificadas desta problemática.

Constatamos também neste segmento social a contradição existente no seio da sociedade brasileira quanto ao modelo de desenvolvimento econômico e social que adotamos 
que além de excludente, contribui para dificultar ainda mais a unificação da pauta de luta de defesa de direitos dessas pessoas, pois é muito difícil agrupar a todos.

Não obstante, fica claro também na avaliação que nos propusemos a fazer para elaborar esta Monografia, que a ótica da garantia dos Direitos Humanos sempre representou uma linha norteadora e de unificação para todos, galvanizando contingentes mais expressivos capazes de se fazerem ouvir.

Identifica-se, ainda, com a observação do percurso trilhado para a defesa dos interesses das diversas peculiaridades de cada deficiência, a necessidade da organização desses cidadãos e suas famílias como movimento social que respalde o trabalho cotidiano de garantia e manutenção dos direitos.

Para alcançar o nível de cidadania devido a esses cidadãos, que os inclua naturalmente em todas as iniciativas da sociedade e do Estado, tratando-os realmente sob a ótica da possibilidade do exercício da cidadania plena, respeitando e compreendendo a sua singularidade e atendendo as suas necessidades especiais ou específicas; precisamos dialogar com a sociedade e desnudar esta peculiaridade humana.

As Políticas Afirmativas configuram-se como ferramentas promotoras da igualdade, abrindo espaços para a convivência comunitária e inclusão social, econômica e cultural das pessoas com deficiência e suas famílias e possibilitam e incentivam esse debate.

Esta forma de enfrentar as desigualdades sociais tem se mostrado eficaz desde a sua implantação. Com o passar dos anos parcelas de pessoas com deficiência têm entrado no mercado de trabalho por meio das vagas especiais nos concursos públicos, ou através de reservas de mercado no setor privado definidos pela legislação, levando esses contingentes a dispor de níveis de renda que lhes possibilitam exercer alguma cidadania. É verdade que estamos muito longe dos números que as estatísticas nos impõem, entretanto já podemos depreender do percurso já trilhado, que o encaminhamento é correto, e que com uma aplicação perene no decorrer dos anos, a tendência é o alcance da equalização das oportunidades.

Como a deficiência é uma das características humanas e sempre esteve presente na história da humanidade, primeiramente tratada como moléstias que causavam grande inquietação aos humanos, e, na medida em que a civilização industrial, baseada na eficiência, tem negado a cidadania e a participação plena no processo de desenvolvimento econômico, social e cultural às pessoas com deficiência, precisamos debater sobre a criação de mecanismos que alterem positivamente esta realidade. 
Portanto, é fundamental que estabeleçamos um diálogo permanente com a sociedade brasileira, produzindo conhecimento prático e teórico que contemple um debate aprofundado e que resgate a história desses brasileiros, e como se construiu a exclusão social histórica a que estão submetidos, buscando e propondo caminhos que os coloquem num patamar de cidadania e respeito social.

Neste contexto, as questões relacionadas à deficiência e suas conseqüências para a inclusão ou exclusão social do indivíduo explicitam, em última análise, a necessidade da construção de uma sociedade acolhedora e capaz de conviver com a sua diversidade.

Os Estados têm que proporcionar às Políticas Públicas os meios necessários para a assimilação desses indivíduos, e a sociedade instada a cumprir a sua parcela de responsabilidade quanto ao cumprimento dos direitos diferenciados destes cidadãos como um elemento que eleva a própria sociedade a um patamar de desenvolvimento humano prazeroso para se existir, abandonando o viés assistencialista e paternalista ainda muito presente, que retira o assunto da esfera da cidadania.

Ao lado do Estado, as organizações sociais ligadas ao segmento precisam definir seu papel: Entidades de Defesa de Direitos, que buscam uma interlocução permanente com o Estado e com a sociedade para garantir e efetivar a participação social desse grupo de brasileiros, ou Entidades que vão para o mercado, colocando seu fortalecimento institucional como prioridade na sua atuação.

Enfim, para desenharmos caminhos e percursos que levem a uma abordagem adequada de enfrentamento deste importante e singular problema social, que sempre fez e sempre fará parte da humanidade, buscaremos trazer para o diálogo que manteremos na Monografia, a titulo de curiosidade, um pouco da saga vivenciada pelos humanos com deficiência no curso da história da espécie humana e as conquistas e os desafios que foram vencidos por eles, para chegar ao Brasil dos dias atuais, onde centraremos nossos esforços de forma mais veemente, e debater acerca dos desafios que ainda estão colocados para serem superados no horizonte deste grupo de brasileiros e sobre os fundamentos da cidadania na história do ocidente, que representa o paradigma da igualdade humana para nossa cultura.

É um esforço acadêmico de pesquisa documental que busca recuperar e explicitar a história da deficiência considerando as seguintes questões:

- A sua existência como característica humana;

- O desenvolvimento do processo de Cidadania e dos Direitos Humanos na Civilização Ocidental; 
- O estudo da História da Organização das Pessoas com Deficiência no Brasil;

- Os avanços obtidos pela Organização das Pessoas com Deficiência no Brasil;

A trajetória de construção da cidadania das pessoas com deficiência no Brasil para servir como instrumento/ferramenta de apoio para o desenvolvimento de estudos e ações destinadas a este público, bem como de informação e conhecimento acerca do tema, para contribuir com a conscientização da sociedade brasileira sobre a magnitude desta questão social, além de explicitar a necessidade do seu enfrentamento com propriedade, são elementos imprescindíveis para a abordagem desta questão social.

Assim, para desenvolver o Trabalho, procuramos, inicialmente, introduzir no Capítulo I elementos que chamassem a atenção para este problema, fazendo o leitor compreender que estava adentrando em um tema que mesmo sem "aparecer" sempre esteve presente na história humana, resgatando sua presença no Planeta desde os tempos em que se tem notícia dos primeiros agrupamentos humanos até os dias atuais, para chegarmos à sociedade industrial, que multiplicou as dificuldades de participação para as pessoas com deficiência.

No Capítulo II, é apresentada a concepção do desenvolvimento do conceito de cidadania que nos referenciamos para embasar as lutas dos movimentos sociais que participamos, por acreditar que quando vamos à gênese dos fatos conseguimos encontrar o fio condutor para empreendermos as ações de construção e reconstrução cotidianas da própria cidadania.

Para completar o ciclo da análise e enveredar a discussão para a realidade brasileira, debruçamo-nos na minha própria vivência de 23 (vinte e três) anos de “cadeirante” e toda uma história de participação no Movimento Social que criamos no Brasil para dar encaminhamento às questões afetas à pessoa com deficiência - da qual me orgulho imensamente -, para estabelecer uma relação causal com uma exclusão social identificada, originada num modelo de desenvolvimento social, econômico e cultural que não abrange todos os indivíduos do espectro social, tentando ser superada por ações pontuais que não descronificam este sério problema social, e sim empurram para um futuro sem data marcada sua solução, e propor caminhos para superação de uma das mais graves questões sociais que acompanham a sociedade.

Identificamos, por fim, que para superarmos a brutal exclusão social das pessoas com deficiência em nossa sociedade, precisamos, num sentido, buscar a alteração do modelo de distribuição das riquezas que produzimos socialmente e, paralelamente, construir políticas públicas capazes de efetivar esse enfrentamento de forma dinâmica e progressiva, 
estabelecendo o ambiente de convívio pessoal compatível com o grau de desenvolvimento da sociedade moderna em que vivemos. 


\section{ABORDAGEM TEÓRICO-METODOLÓGICA}

Para a elaboração desta monografia utilizamos e realizamos uma pesquisa documental, e bibliográfica, baseada na pesquisa de títulos conhecidos durante a graduação em Serviço Social na Universidade de Brasília - UnB e outros aprendizados, e a partir de uma revisão analítica da literatura disponível sobre a história da deficiência de que disponho em minha biblioteca pessoal, acumulada nos mais de vinte anos de militância na causa, e da trajetória da construção dos conceitos de Cidadania e Direitos Humanos na Sociedade Ocidental que nos permitiu recolher as informações necessárias para análise e entendimento da problemática vivenciada pelas pessoas com deficiência no transcorrer da história brasileira.

A militância nesta área também propiciou que pudéssemos estabelecer conversas informais e participar de reuniões e lutas no sentido da garantia e efetivação de políticas que atendam a construção de uma cidadania real para as pessoas com deficiência, que possibilitaram o aprofundamento exigido para um mapeamento eficaz de assunto de tamanha complexidade.

A vivência pessoal das dificuldades colocadas para esta população trouxe na marra a disposição para lutar contra essas dificuldades.

A escolha do curso de Serviço Social, inclusive é fruto do processo de formação social e política a que fui submetido pela oportunidade que tive de participar dessas lutas sociais.

As categorias de análise que utilizei para minha análise compreendem:

- Deficiência - Compreendida como toda e qualquer limitação ou incapacidade que atinja o homem desde os tempos imemoriais, cunhada quando as pessoas com limitações e incapacidades foram consideradas “deficientes” para as linhas de montagem da indústria que nascia; (embora eu, particularmente, entenda este termo como inadequado, considero que ele é de largo uso pela linguagem coloquial e até culta, e acabou impondo-se como síntese conceitual)

- Cidadania - Entendida como o acúmulo histórico de todas as lutas sociais empreendidas em favor da liberdade, da igualdade e da fraternidade, do processo de construção dos Direitos Humanos como contrato mínimo positivado entre os povos de respeito para convivência entre as pessoas e as suas diferentes culturas, e toda a luta de organização empreendida pelos segmentos organizados da sociedade civil em busca de reconhecimento social; 
- Trabalho - Percebido, segundo o método histórico materialista dialético, como elemento fundamental para inclusão das pessoas com deficiência no mercado de trabalho e como forma de criar as condições de suficiência para o exercício da cidadania. Em Karl Marx, considerando o modo como o autor descreve as relações de trabalho no interior da sociedade Capitalista, esta relação aparece como um dos principais entraves para inclusão laboral das pessoas com deficiência. Na cidadania regulada só os incluídos acabam exercendo a cidadania, mesmo que não seja plena. A plenitude vai depender do nível de renda disponível. Marx enfatiza na discussão sobre o trabalho e o assalariamento, os aspectos que tem a ver com a construção da mais-valia, aquilo que subjuga os indivíduos à venda de sua força de trabalho, criando um excedente de retorno da produção, normalmente em valor financeiro, para o proprietário dos meios de produção. Neste sentido, a exploração em cima do trabalhador “deficiente” é muito maior. Normalmente, o que Marx costuma falar sobre mais-valia está situado na ilustração das oito horas diárias de trabalho, onde temos o cálculo que as primeiras quatro horas correspoderiam ao tempo gerador da produtividade, e as quatro horas restantes seria justamente aquilo que gera o excedente produtivo, motivo de acumulação nas finanças do proprietário, seja esse industriário, dono de comércio, ou simplesmente alguém que contrata a mão-de-obra do trabalhador como força produtiva. Para K. M “o excedente seria não só um valor que não faz parte dos custos de produção mas também dum possível valor para a construção de um novo capital a ser investido em outras áreas ou a ser utilizado na expansão da produção”. Para debatermos sobre a inclusão das pessoas com deficiência dentro do Sistema Capitalista de Produção, onde as pessoas comuns, sem deficiência, encontram extrema dificuldade para se inserir, a Categoria Analítica Trabalho é central para desvendar os caminhos a serem percorridos para se assegurar essa inclusão social.

Para sustentar a afirmativa sobre minha participação no Movimento Nacional de Defesa dos Direitos das Pessoas Portadoras de Deficiência e quanto ao prisma de observação de que participei deste Movimento de Luta, apresento as principais experiências profissionais, trabalhos que participei e funções que desempenhei e desempenho em defesa dos nossos direitos e trabalhando pela efetivação de nossa cidadania, dispostos a seguir: 
* secretário executivo da confederação brasileira de basquetebol em cadeira de rodas - cbbc;

(brasília - df, 2005 até a presente data)

* coordenador da associação brasileira de desportos em cadeira de rodas - abradecar;

(brasília - df, 2005)

* assessor parlamentar do deputado paulo tadeu, pt-df, na câmara legislativa do distrito federal;

(brasília - df, 1999 até janeiro de 2005)

* presidente e vice-presidente do conselho de assistência social do distrito federal;

(brasília-df, 1996 / 1997)

* coordenador para integração da pessoa portadora de deficiência do distrito federal;

(brasília-df, 1995 até 1998)

* assessor da coordenadoria nacional para integração da pessoa portadora de deficiência - corde/ministério do bem-estar social;

(brasília - df, de 1990 até o primeiro semestre de 1994)

* vice-presidente do "seminário regional para a américa latina sobre programas nacionais para pessoas portadoras de deficiência", na qualidade de representante das organizações não governamentais brasileiras;

(san josé - costa rica, de 07 a 10/03/94)

* integrante da comissão de elaboração da lei orgânica de assistência social como representante da corde ministério do bem estar social/governo federal;

(brasília - df, 1990 a 1994)

* diretor-substituto da assessoria de planejamento da direção nacional da legião brasileira de assistência/lba;

(brasília, 1994 a 1995)

* palestrante do "ix encontro de profissionais que atuam na área de educação para o trabalho";

(florianópolis - sc, de 03 a 05/11/93)

* participante do "encontro nacional com procuradores da república e de justiça", promovido pela coordenadoria nacional para integração da pessoa portadora de deficiência - corde, e universidade católica de petrópolis/rj;

(petrópolis - rj, de 06 a 08/10/93)

* organizador do seminário "reabilitação profissional e inserção do portador de deficiência no mercado de trabalho";

(brasília - df, de 02 a 03/07/93)

* palestrante do "i encontro municipal para estudos das questões sociais das pessoas portadoras de necessidades especiais", realizado pela associação matogrossense dos municípios - a.m.m;

(cuiabá - mt, de 14 a 15/04/93)

* representante da entidade "deficientes democratas do distrito federal - ddd/df" no "v encontro nacional de entidades de deficientes físicos", promovido pela 
organização nacional de entidades de deficientes físicos onedef;

(belém - pa, de 06 a 09/08/92)

* membro da comissão paraolímpica brasileira, designado pelo secretário de desportos da presidência da república (portaria $n^{\circ}$ 024/91, de 22 de abril de 1991) para representar o governo brasileiro nas paraolimpíadas realizadas em barcelona - espanha;

(barcelona - espanha, de 26/08 a 14/09/92)

* participante do "encontro sul-brasileiro - século da diferença", realizado pela fundação catarinense de educação especial;

(são josé - sc, de 10 a 14/12/91)

* participante da palestra "desenvolvimento econômico, meio ambiente e pessoa portadora de deficiência", promovida pela secretaria de governo do município do rio de janeiro, conselho municipal de defesa dos direitos e movimento nacional de defesa dos direitos da pessoa portadora de deficiência, em comemoração ao dia nacional de luta deste segmento - 21 de setembro;

(rio de janeiro - rj, 21/09/91)

* expositor do "ii seminário nacional dos estados e municípios sobre políticas sociais";

(fortaleza - ce, de 26 a 28/08/91)

* participante do "1 ${ }^{\circ}$ congresso brasileiro de comunicação e estigma a imagem do portador de deficiência através da mídia";

(rio de janeiro - rj, de 27 a 29/05/91)

* integrante da comissão de elaboração dos dispositivos constitucionais referentes à pessoa portadora de deficiência assembléia nacional constituinte - subcomissão das minorias / congresso nacional;

(brasília - $d f, 1986 / 8)$

* secretário parlamentar da câmara dos deputados gabinete do deputado nélson seixas, presidente da federação nacional das associações de pais e amigos dos excepcionais;

(brasília - df, 1988/9)

* assessor da secretaria de ação comunitária (seac) programa de atenção à pessoa portadora de deficiência; (ministério da cultura/ brasília - df, 1987)

principais trabalhos:

* membro do grupo de trabalho responsável pela elaboraçào dos dispositivos constitucionais referentes ás pessoas portadoras de deficiência;

* membro do grupo de trabalho responsável pela elaboração da lei orgânica de assistência social;

(lei $n^{\circ}$ 8742/93, regulamentação da constituição federal arts. 203, 204)

* consultoria à gallaudet university, washington, dc-eua, para organização social e formação de líderes para atuar com a integração social do portador de deficiência na américa latina; 
(córdoba - argentina, 1993)

* vice-presidente do "seminário regional para américa latina sobre programas nacionais para pessoas portadoras de deficiência ", apresentando a realidade brasileira, na qualidade de representante das ongs brasileiras que atuam na área;

(san josé - costa rica, 1994)

* membro do grupo de coordenação da equipe paraolímpica brasileira nos jogos de barcelona/1992;

* consultoria e assessoria a diversos parlamentares, nos três níveis legislativos, na elaboração de dispositivos legais relativos às pessoas portadoras de deficiência;

* elaboração da política nacional para integração da pessoa portadora de deficiência - corde/mj/sdc;

* membro da equipe de reestruturação da coordenadoria nacional para integração da pessoa portadora de deficiência;

* membro da equipe de trabalho responsável pelo processo de reordenamento institucional da política de assistência social / mbes/corde;

* criação de equipamento para viabilizar o ingresso de pessoas com mobilidade reduzida ao sistema de transporte coletivo;

cargos e funções exercidas:

* assessor parlamentar / câmara dos deputados e legislativa;

* assessor técnico do programa de atenção à pessoa portadora de deficiência da secretaria de ação comunitária do ministério da cultura;

* assessor técnico da federação nacional das associações de pais e amigos dos excepcionais - fenapae;

* assessor da coordenadoria nacional para integração da pessoa portadora de deficiência - corde;

* diretor-substituto da assessoria de planejamento da direção nacional da fundação legião brasileira de assistência - lba;

* coordenador para integração da pessoa portadora de deficiência do distrito federal - corde/df;

* presidente e vice-presidente do conselho de assistência social do distrito federal;

* coordenador da associação brasileira de desportos em cadeira de rodas - abradecar;

* secretário executivo da confederação brasileira de basquetebol em cadeira de rodas - cbbc;

São momentos que vivi e histórias de vida que presenciei que à luz de uma compreensão mais ampla da realidade, que se dá através da utilização do marco teórico do método histórico e materialista dialético de Karl Marx, permite que a análise do objeto de estudo desta monografia que é a trajetória de construção da cidadania das pessoas com deficiência no Brasil seja melhor aprofundada. 
Este método propiciou na busca de compreensão deste fenômeno o alcance de determinações mais simples, que não aparecem numa primeira observação da realidade e provoca a obtenção de uma rica totalidade de determinações e relações diversas. Pois daí deriva que, para Marx, "O concreto é concreto, porque é a concentração de muitas determinações, isto é, unidade do diverso.” (MARX, in FERNANDES(Org), 1984:.410)

O desvelamento da realidade ao tempo em que é o resultado do processo da concentração é também o verdadeiro ponto de partida. Quer dizer, “O objeto real [reale subjekt] permanece em pé antes e depois, isto é, a cabeça não se comporta senão especulativamente, teoricamente... [onde] as determinações abstratas conduzem à reprodução do concreto por meio do pensamento.”(IDEM:411) 


\section{APRESENTAÇÃO E ANÁLISE DO OBJETO DE ESTUDO}

\section{CAPÍTULO I}

\section{A Presença dos Humanos com Deficiência sob a Terra}

Ao nos debruçarmos no estudo da evolução da espécie humana e da trajetória das pessoas com moléstias incapacitantes - chamadas de deficiência a partir da Revolução Industrial - no curso desta evolução temos que compreender como pano de fundo desta reflexão, que, segundo Silva (1986) as deficiências/moléstias “sempre existiram” no seio das comunidades e agrupamentos humanos desde os mais remotos tempos, e que os indivíduos sobreviviam a elas, e que mesmo agora, na contemporaneidade, por mais que tecnologias fabulosas sejam criadas, inventadas e desenvolvidas, “existem, e sempre existirão”.

É na interação com a natureza que a fragilidade biológica humana encontra o ambiente capaz de estabelecer as possibilidades de sua ocorrência, tornando-a uma das tantas e inexoráveis características humanas.

Nas pinturas rupestres desvendadas pelos arqueólogos e paleontólogos na Europa Ocidental encontramos figuras retratadas com determinadas partes de seus corpos amputados fazendo parte das atividades cotidianas, o que comprova a presença e a participação das pessoas com deficiência no alvorecer da espécie humana e, no mínimo, que eram reabilitados ou recuperados para este retorno ao convívio social, mesmo que em funções diversas das que desempenhavam antes da sua incidência e conseqüente incapacidade, a partir dos fatos constatados pela arqueologia e pela paleontologia que comprovam esta sobrevivência, como o aparecimento de indícios e evidências que nos revelam o desenvolvimento da medicina rudimentar, dos achados de fósseis com fraturas solidificadas e dos crânios trepanados, além de inúmeras outras evidências dessa presença.

Na análise dos ossos pré-históricos são observados elementos suficientes para comprovar a ruptura e a consolidação de fraturas, que por si só já denotam a existência, mesmo que rudimentar, de cuidados sociais e de ordem médica.

Segundo o Dr. Edgard M. Bick, citado por Agüero, conforme relata Silva (1986), “o homem pré-histórico que inventou a imobilização de um membro fraturado - tala - mereceria a mesma honra e teria os mesmos méritos que aquele que idealizou a roda ou que descobriu a forma de fazer e de controlar o fogo". 
A constatação científica dos fatos em comento, que serão relatados no curso deste trabalho, fazem parte do meu esforço preambular para introduzir o debate de tema tão apaixonante, e consolidar com o leitor um elo que nos faça ansiar por conhecer a peculiaridade interessante desta "história dentro da história humana" que chegará, ao final, ao Brasil dos dias atuais, e começar a estabelecer paradigmas que possam nutrir os aspectos que serão colocados para debate e reflexão científica, analítica e dialética sobre o papel e a participação desses indivíduos na construção de nossa espécie e de nosso País.

Este passeio histórico introdutório que trazemos pretende aguçar a curiosidade do leitor e produzir uma espécie de encantamento por tão fabulosa saga vivenciada pelos humanos com deficiência desde os primórdios do desenvolvimento de nossa espécie até os dias de hoje, e contribuir para a construção de uma concepção de sociedade fundada no respeito entre os indivíduos e os povos.

Abrindo nossa reflexão sobre o desenvolvimento da espécie humana sob a terra desde os primórdios que a paleontologia conseguiu demarcar, agora por este ângulo pouco explorado, pretendo conseguir misturar elementos tal qual um alquimista, que sejam capazes de representar o amálgama a consolidar a multiplicação de parceiros de responsabilidade social imbuídos da construção e transformação social que tanto precisamos efetivar na sociedade contemporânea, que espero colher das análises, debates e reflexões dialéticas que partilharemos neste trabalho acadêmico.

É na prática cotidiana de convivência comunitária histórica do ser humano que pretendo construir o eixo condutor de nossa viagem, desnudando a trajetória e a realidade atual desses brasileiros e o desenvolvimento de sua organização como Movimento Social no Cenário Nacional, ao mesmo tempo em que elaboro a contribuição acadêmica que julgo importante produzir como testemunho de minha passagem no curso de Serviço Social na Universidade de Brasília.

2. A História dos Humanos com Deficiência desde as Épocas Remotas da Civilização até a Idade Média

A Arqueologia classifica as diversas etapas da vida dos humanos sob o Planeta relacionando o Período vivido, com o principal material utilizado no fabrico dos utensílios e ferramentas relacionadas à sobrevivência e ao conforto daqueles humanos primitivos na sua interação com a natureza. 
Mesmo sendo extremamente complicado do ponto de vista de uma análise sociológica profunda identificar o tratamento dispensado aos humanos com deficiência nos Períodos Históricos mais primitivos como o Paleolítico, o Mesolítico e o Neolítico, duas características são constantes na espécie desde o seu aparecimento sob a Terra: A vida em agrupamentos, e a conseqüente proteção mútua; e a necessidade e o gosto por deambular por ai. Desde sempre o ser humano vai e vem, seja por vontade, seja por necessidade. Ser transeunte é também natural e inerente à espécie - por isso a negação dessa possibilidade hoje vai de encontro à natureza.

O desenvolvimento do processo civilizatório é marcado pela experimentação e pelo acúmulo de experiência e conhecimento, e acontece de forma diversa em cada parte do Planeta segundo as condições naturais oferecidas, mas é no Homem Neolítico que encontraremos os primitivos e rudimentares elementos de uma consciência social, e é de onde podemos partir com mais segurança para traçar a trajetória dos humanos com moléstias, incapacidades e limitações sob a Terra.

Impende destacar também, nesta fase inicial de nossa reflexão, que determinados males incapacitantes como amputações diversas, cegueiras ou limitações de acuidade visual, surdez ou diminuição da capacidade auditiva, síndromes diversas, deficiências mentais de variados graus, diversas formas de deficiências físicas oriundas de trauma ou vetores orgânicos, além das mais diversas formas patológicas identificadas pela medicina, sempre acompanharam o Homem e seus agrupamentos, trazendo para o seu cotidiano a realidade do enfrentamento social dessas situações.

Não é difícil imaginar ou até afirmar que no Período conhecido como Idade dos Metais, quando conseguimos alcançar um registro mais apurado da construção do processo civilizatório da humanidade, que as práticas sociais encontradas correspondam a uma construção histórica e instintiva, pois a própria ciência com suas constatações arqueológicas nos autorizam a esta compreensão, na medida em que nessas análises e investigações são identificados os elementos capazes de comprovar esta afirmação, pois aparecem os indícios de atenção aos males que atingiam aos indivíduos.

Os achados arqueológicos nos trazem por um lado à convicção do desenvolvimento do processo civilizatório como uma trajetória eivada de desafios e conquistas, que mostram sempre uma capacidade imensurável de superação dos seres humanos frente aos desafios colocados pelas intempéries, calcada especialmente no componente biológico da racionalidade a eles facultado pela natureza e, por outro, desnudam o esforço empreendido na 
construção de organizações sociais dos mais variados matizes que nada mais pretendem do que preservar a espécie.

Como argumento a sustentar as afirmações exaradas sobre a presença de homens com moléstias incapacitantes e limitações convivendo nos agrupamentos mais remotos, precisamos nos apoiar nos estudos de uma nova especialidade da paleontologia, a paleopatologia, que busca a partir dos achados de ossos pré-históricos indicar a existência de patologias incapacitantes e/ou causadoras de incapacidade/deficiência nos seres humanos. Apóia-se a paleopatologia para referendar sua tese nas descobertas que permitiram a identificação de ossos com anomalias e moléstias que levem a limitação e incapacidades em fósseis que estavam em situação de convívio social nos agrupamentos humanos constituídos, referido por Silva, dos quais pinçamos os exemplos citados abaixo:

- $\quad$ "Pythecanthropus Erectus - Existem poucos ossos do tipo conhecido por esse nome científico: uma calota craniana, três dentes e um fêmur. O Fêmur apresenta uma espécie de tumor ósseo bem volumoso no terço superior, próximo à sua cabeça, atribuído pelos estudiosos a um fratura ou a um aneurisma;

- Homem de Neanderthal - Há ossos do chamado Homem de Neanderthal que apresentam traços de traumatismo. Há, por exemplo, no úmero esquerdo, uma cicatriz que corresponde a uma lesão séria. No esqueleto desta espécie, descoberto em Krapina, existe um sinal de fratura solidificada na clavícula. O esqueleto de La Chapelle-aux-Saints mostra sinais de artrite deformante;

- $O$ esqueleto analisado por Raymond - $O$ fêmur com grande desvio citado mais atrás, foi descoberto por Raymond na gruta de Baye. É interessante notar que ossos provenientes dessa mesma caverna apresentam, quase todos, sinais de osteoartrite de natureza reumática. Segundo alguns especialistas, essa afecção apresenta-se como um real obstáculo à boa solidificação de uma fratura;

- Homem Cro-Magnon - A espondilose foi encontrada num esqueleto de homem pré-histórico conhecido como Cro-Mognon. Trata-se de um mal de efeitos muito limitadores, pois a espinha dorsal em geral fica com uma curvatura bastante acentuad, a cabeça inclina-se para a frente e as coxas flexionam-se

- Freqüência do Reumatismo - O reumatismo foi muito freqüente de devastador na Pré-História. Havia casos que iam desde a chamada osteopatia, até a total imobilização do homem primitivo. Um exemplo marcante é encontrado em ossos do Homem de Neanderthal, descobertos em La Chapelle-aux-Saints, na França. Pela análise dos mesmos, especialistas constataram sinais 
claros de articulações coxo-femurais com artrite seca $e$ com poli-artrite." (silva, 1986:35)

Quando afirmamos peremptoriamente que as pessoas com moléstias, limitações e incapacidades estavam presentes nos agrupamentos humanos desde os primórdios da humanidade e isto representava um problema social, estamos falando de uma situação onde a espécie humana enfrentava a natureza e suas intempéries literalmente de "peito aberto”, com armas rudimentares e de curto alcance que os obrigava a um embate muito duro para sobreviver onde o risco da incidência de acidentes e moléstias causadoras de limitações e incapacidades era muito grande e a proteção mútua, embrião da sociedade, indispensável para a sobrevivência.

A medicina rudimentar primitiva já se inquietava com esta manifestação no seio da espécie e os cuidados sociais que a paleopatologia identificou como o uso da "tala” para reduzir fraturas são evidências suficientes para imaginarmos a permanência desses humanos no convívio de nossos ancestrais.

Ao mesmo tempo, não estamos querendo escamotear uma realidade também presente nesta mesma história que, ao contrário da aceitação, apoio e assimilação, é marcada pelo abandono, pela segregação ou destruição, pelo extermínio e até pela ridicularização, pelas mais variadas motivações. Queremos apenas mostrar a sua presença e que em alguns momentos e em alguns lugares permaneciam vivos junto aos agrupamentos de origem.

Encontraremos as situações descritas acima em todas as fases da humanidade, ora de aceitação, comiseração, pena e recuperação, ora de discriminação, ridicularização, asco e extermínio, dependendo do lugar e dos aspectos naturais, culturais e de sobrevivência envolvidos com o agrupamento humano que se imagine e sua relação com a natureza local, e esta diversidade de tratamento e atenção acompanhará a humanidade por toda a sua trajetória civilizatória, configurando uma verdadeira saga vivenciada por uma expressiva parcela de seres humanos.

É importante trazermos também para a reflexão dos trabalhos que pretendermos desenvolver na prática profissional como assistentes sociais sobre e junto a este segmento social os aspectos relacionados a uma certa tendência de magificação das deficiências, que sempre acompanhou o homem desde os mais remotos tempos e advém da própria incompreensão do homem sobre a deficiência.

É o simbolismo que a deficiência possui que permite a construção da possibilidade de magificação e leva as pessoas com deficiência a serem alvo dos “curandeiros” que buscam curas espetaculares e milagrosas, e objeto de análise e avaliação das religiões e crenças, que 
as relacionam a diversas possibilidades de contatos mais estreitos com o Divino, criando dogmas e estigmas positivos e negativos que contribuem para um certo encantamento do tema, prejudicial para o estabelecimento da normalização das relações sociais que precisa ser introjetada na percepção social para o equacionamento correto da questão.

Encontramos referências ligando a deficiência a castigos divinos, superstições e encantamentos que grassam desde a representação do Bem, até a representação do Mal sob a terra, que produziram e até hoje produzem as mais diferentes reações, dependendo da cultura onde ela se manifesta.

A deficiência trouxe ao homem uma percepção incômoda da existência do sobrenatural pela sua própria incompreensão quanto à existência dos males, notadamente os que acompanham os indivíduos desde o nascimento, que fazem uma ligação direta com o mundo da imaginação; é um receio legítimo de vir a portar qualquer dos males conhecidos; é o medo do homem de merecer um castigo advindo de um ser superior, capaz de impor uma situação de privação/incapacidade, como a da deficiência, em função de atos julgados impróprios pelo entendimento dos preceitos/tabus/dogmas de sua cultura; é a percepção de sua própria fragilidade biológica que o deixa vulnerável a ela que o inquieta; e está incompreensão acerca da deficiência - de onde ela vem? Será que do mesmo lugar que vem o "perfeito" do "Divino”? - a magificação - ainda hoje representa um elemento que dificulta a sua assimilação pura e simples ao convívio social.

Assim, na prática cotidiana de atenção às questões relacionadas à deficiência e aos deficientes o Assistente Social encontrará uma multiplicidade de cenários desafiadores bastante intensos:

- Conhecer a realidade da pessoa deficiente;

- Como encaminhar as questões relacionadas à defesa dos direitos;

- As necessidades das diversas formas em que a deficiência se apresenta, implicarão na busca de conhecimento específico;

- A dificuldade de delimitar um corte seletivo relacionado à renda do usuário;

- O conhecimento e a relação com toda a rede de atenção disponível nos setores público e privado é imprescindível;

- Conhecimento da pauta de necessidades sociais do segmento. 
Portanto, quando apresentamos a deficiência como uma questão social que acompanha o homem desde sempre e que sua percepção por parte do profissional de assistência social precisa ser ontológica e calcada no processo de construção histórica da sociedade, o fazemos porque temos convicção de que é nessa análise que encontrará os paradigmas que vão nutrir uma prática cotidiana capaz de alterar positiva e progressivamente a realidade das pessoas com deficiência que com eles estiverem.

\section{Os Humanos com Deficiência e a Sociedade Industrial}

Com certeza os primeiros humanos com deficiência que habitavam as cavernas não imaginariam que no futuro das pessoas com características semelhantes as suas haveria um momento do desenvolvimento da civilização em que apareceria um obstáculo ainda maior do que os enfrentados por eles nos primórdios, quando as intempéries eram titânicas frente à fragilidade humana, e nem existia uma civilização para se apoiar, a ser enfrentado para garantir a presença nos agrupamentos como nos tempos imemoriais: O surgimento da Sociedade Industrial.

Segundo Marcio Tavares d’Amaral (2004), na civilização da eficácia, da capacidade de produzir efeitos, onde tudo é medido segundo a capacidade de produção do indivíduo dentro da cadeia industrial, a imensurável capacidade humana de produzir efeitos a partir de sua singularidade perde valor, e as pessoas tendem a ser niveladas por uma capacidade média que descarta os indivíduos que não conseguem atingi-la. Neste prisma, nada melhor que cunhar o termo apropriado para aquele momento de revolução da sociedade para este grupo de trabalhadores: “DEFICIENTES”. Deficientes para o modo de produção e consumo que se impunha à civilização naquele momento, que era denunciado como danoso para a singularidade humana pelos observadores mais atentos das ciências sociais.

Como contraponto a esta posição discriminatória explicitada na categoria acima, encontramos, em Henry Ford, um dos precursores da explosão industrial americana que se sucedeu no começo do Século XX, conhecido como criador do processo de organização industrial que permitiu a retirada do máximo de produtividade da mão-de-obra empregada na indústria e idealizador da linha de montagem, uma visão inusitada e positiva do papel que poderiam desempenhar as pessoas com limitações e incapacidades no mundo da indústria, conforme citação abaixo: 
“Um cego ou um mutilado é capaz (...) de efetuar o mesmo trabalho e ganhar o mesmo salário que um homem completamente são. Seria inteiramente oposto aos nossos propósitos que, em vista dos defeitos físicos dos operários, procurássemos admiti-los com salários reduzidos, contentando-nos com um tipo inferior de produção. É um desperdício empregar um homem perfeito para um trabalho que pode ser executado por um aleijado. É um desperdício horrível pôr cegos a trançar cestos.” Henry Ford, 1925.

Hoje, paradoxalmente, este modelo de desenvolvimento que se apresentava como inquestionável para a equação social e poderia ter incluído as pessoas com deficiência conforme diagnosticava um dos inventores da indústria de transformação apresenta, ao contrário, inúmeros efeitos negativos que atingem a todos indistintamente, e de forma implacável os “deficientes”, excluindo-os do processo de desenvolvimento sócio, econômico e cultural e ainda está a ameaçar a existência do Planeta.

Mesmo assim, o modelo foi imposto, e seu desenvolvimento inexorável atropelou todas as advertências e chegou aos tempos atuais, e a peça mais frágil de toda esta engrenagem - o ser humano - enfrenta problemas de inserção social, já diagnosticados por Marx e Engls no século XIX quanto a este modelo, construindo um ambiente ainda mais hostil para as pessoas com deficiência, pois a sua grande potencialidade esta justamente localizada na capacidade singular de criação humana, desprezada pela sociedade industrial de consumo.

Neste contexto o ser humano com deficiência vivenciou e ainda vive um momento delicado para garantir a sua presença nos agrupamentos sociais. O acesso aos recursos para sobrevivência que deveriam vir do trabalho ou de algum tipo de proteção social capaz de garantir seus Direitos Humanos é precário e a vulnerabilidade social se acentua de forma evidente: somando-se a exclusão, a pobreza e a deficiência, encontramos uma equação social extremamente complexa para ser decifrada e nela o Estado tem que desempenhar um papel de protagonismo, sob pena dos contingentes de seres humanos com deficiência sequer terem o direito de desfrutar dos Direitos Humanos instituídos pela humanidade.

Um dos mecanismos encontrados para equacionar a superação desta situação social de exclusão laboral causada pela competitividade do mercado, configurado nos dispositivos legais que estabelecem quotas para deficientes no mundo do trabalho, público e privado, aliado ao oferecimento de oportunidades de habilitação e reabilitação, como "Políticas de Afirmação de Direitos”, tem possibilitado a transformação social de contingentes expressivos de representantes deste grupo. O processo foi deflagrado com o advento da Constituição de 1988, mas a equalização de oportunidades só acontecerá com aplicação perene das normas. 
Ao mesmo tempo, a falta de preparo para assumir os postos disponíveis no mercado por força desta mesma legislação, que têm sua origem num processo de exclusão histórico de atenção das políticas públicas tradicionais formadoras do cidadão, e a falta de infra-estrutura urbana que permita o deslocamento natural a esses indivíduos pelos locais de uso coletivo são entraves básicos a serem superados e impedem uma evolução mais célere desta desigualdade social.

Está provado que os deficientes desempenham atividades laborais mesmo dentro do mercado competitivo com eficiência e que a partir de sua singularidade contribuem de modo diferenciado, trazendo para o ambiente de trabalho a explicitação da diversidade humana.

Esta exclusão histórica que buscamos superar desde a primeira reunião nacional de 1980 nada mais é do que a ânsia de brasileiros que ainda procuram estabelecer relações sociais capazes de configurar dignidade.

O preconceito, que é fruto da desinformação, e a contra informação, que levam ao entendimento de que a deficiência é algo que representa simbolicamente o defeituoso, ou o Mal, trazem para o universo das pessoas com deficiência uma barreira difícil de ser superada para o processo de inclusão acontecer, que está intimamente relacionada ao que acabamos de considerar. Quanto mais grave a limitação e/ou a incapacidade, maior a dificuldade de inclusão e maiores os preconceitos. O conceito de eficiência da sociedade de consumo não consegue compreender a força de produção da singularidade humana, rotulando as pessoas com limitações e incapacidades, em última análise, como “deficientes” para desempenhar as relações sociais que se espera dos indivíduos, e tendem a subalternizar as pessoas com deficiência. É contra este estigma que lutam insistente e incansavelmente as pessoas comprometidas com a cidadania desses indivíduos.

O próprio conceito de democracia estremece quando nos deparamos com a observação da soma dos elementos indutores de exclusão social no modelo capitalista liberal, pois a promessa de que o mercado vai regular as relações sociais não se materializa e os contingentes que primeiro são excluídos do processo de desenvolvimento são justamente os mais vulneráveis socialmente.

A normalização do mundo do trabalho como elemento de distribuição de riquezas e efetivação das políticas públicas como instrumentos de distribuição e redistribuição de riquezas são, pois, os desafios que estão colocados para a sociedade capitalista.

Ser “deficiente” no Sistema Capitalista significa, enfim, além de superar cotidianamente os obstáculos impostos pela própria natureza às pessoas que têm esta singularidade, neste 
cenário hostil, ser competitivo e buscar forças cotidianamente para superar os preconceitos, os estigmas e os desentendimentos sobre a deficiência, que insistem em desqualificá-lo.

\section{CAPÍTULO II}

\section{O Desenvolvimento da Cidadania no Ocidente}

Neste segundo Capítulo da Monografia, faremos uma problematização relacionando a construção da cidadania das pessoas com deficiência aos limites e possibilidades encontrados pela construção histórica deste conceito no Ocidente.

Para avançarmos na discussão, destrincharemos o conceito de cidadania, liberdade e igualdade como um direito social assegurado por um Estado juridicamente de direito e mediado pela política social.

Para isso, faremos um breve resgate histórico acerca do surgimento e dos fundamentos dos direitos do homem buscando compreender o significado histórico dos conceitos de direito e de cidadania, uma vez que são característicos da formação do Estado moderno e da representação política da relação Estado/Cidadão e não mais do Soberano/Súditos.

Os direitos do homem por mais fundamentais que sejam, são direitos históricos nascidos em certas circunstâncias, caracterizados por lutas em defesa de novas liberdades contra velhos poderes e nascidos de forma gradual.

Em outro momento abordaremos algumas questões a respeito da cidadania no Brasil, sua inter-relação com o Estado e o seu desenvolvimento a partir de 1930 com Getúlio Vargas passando pela Constituição de 1988 até os dias atuais. A idéia de analisarmos o período que vai de 1930 a 2002 surgiu por ter sido uma época que abarcou governos ditatoriais e é caracterizada como um grande massacre da classe trabalhadora - com o seu estatuto de quase não cidadã e quase sem direitos.

Não pretendemos fazer uma análise exaustiva sobre o desenvolvimento da cidadania no Brasil e sim fornecer um breve quadro geral de sua trajetória e prática, uma vez que o resgate histórico é de suma importância para o entendimento da problemática dos portadores de deficiência e para o debate político contemporâneo. 


\section{A Revolução Francesa e os Direitos do Homem}

Com a Revolução Francesa, entrou prepotentemente na imaginação do homem à idéia de um evento político extraordinário que rompendo a continuidade do curso histórico, assinalou o fim de uma época e o início de outra. Duas datas próximas entre si podem ser elevadas a símbolos desses dois momentos: 04 de agosto de 1789, quando os nobres renunciaram aos seus privilégios assinalando assim o fim do regime feudal e o 26 de agosto do mesmo ano, quando foi aprovada a Declaração dos Direitos do Homem e do Cidadão, pela Assembléia Nacional, marcando o princípio de uma nova era que atestou o óbito do Antigo Regime, destruído pela revolução, ao serem proclamados os princípios de liberdade, igualdade e fraternidade.

Com efeito, a declaração de 26 de agosto fora precedida pelos Bill of Rights de algumas colônias norte-americanas em lutas contra a metrópole, mas foram os princípios da Revolução Francesa que constituíram a fonte de inspiração ideal para os povos que lutavam por sua liberdade.

A Revolução Francesa foi exaltada e execrada, pois apesar da violência que a acompanhou, transformou profundamente a sociedade européia. Em sua forma mais geral, a ideologia de 1789 era a maçônica sendo responsável pela difusão das exigências da burguesia delineadas na Declaração dos Direitos do Homem e do Cidadão. Esse documento foi um manifesto contra a sociedade hierárquica de privilégios da nobreza, mas não um manifesto a favor de uma sociedade democrática e igualitária. Em seu primeiro artigo, ao dizer que os homens nasciam livres e eram iguais perante a lei, também previa a existência de distinções sociais.

A declaração afirmava que todos os cidadãos tinham o direito de colaborar na elaboração das leis, mas a assembléia representativa não era democraticamente eleita, uma vez que em sua maioria era composta de advogados que desempenhavam um papel econômico importante na França e de homens de negócios, visto que os camponeses e os trabalhadores pobres eram analfabetos e politicamente imaturos.

No entanto, só com a Declaração Universal dos Direitos do Homem, aprovada pela Assembléia Geral das Nações Unidas em 10 de dezembro de 1948, foi que o problema do fundamento dos Direitos Humanos teve solução, uma vez que representou a manifestação da única prova por meio da qual um sistema de valores pôde ser considerado humanamente fundado e, portanto, reconhecido. É uma prova do consenso geral acerca da sua validade. 
Pensando os valores numa perspectiva histórica, percebe-se que o que é evidente num determinado momento, pode não ser em outro. Um exemplo é a questão da propriedade considerada "sagrada e inviolável" para os autores da declaração de 1789 que hoje desapareceu dos documentos das Nações Unidas.

A Declaração Universal dos Direitos do Homem pode ser acolhida como a maior prova histórica dada do consenso sobre um determinado sistema de valores, apesar da difícil tarefa de comprová-lo e efetiva-lo. Com essa declaração, um sistema de valores é - pela primeira vez na história - universal, no sentido de que toda a humanidade partilha de alguns valores comuns uma vez que não foi algo objetivamente construído e sim subjetivamente acolhido pelo universo dos homens. Foi uma lenta conquista e o início de um longo processo construtivo, uma vez que contém o germe da síntese do movimento dialético que começa pela universalidade abstrata dos direitos naturais, transfigura-se na particularidade concreta dos direitos positivos e termina na universalidade concreta dos direitos positivos universais.

\section{A Origem e a Ampliação da Cidadania}

Atribui-se a origem da cidadania, em princípio, à pólis grega que era composta por homens livres, com participação política contínua numa democracia direta, em que o conjunto de suas vidas em coletividade era debatido em função de direitos e deveres. Esse novo ideal de justiça ficava restrito aos grupos privilegiados em função do nascimento ou da fortuna, sobrepondo assim, a justa distribuição dos direitos dos cidadãos enquanto representantes dos interesses da cidade. A nova noção de justiça não diz respeito apenas ao indivíduo e aos interesses da tradição familiar, mas refere-se à sua atuação na comunidade.

Vale ressaltar que quanto mais se desenvolvia a idéia de cidadão ideal, com a consolidação da democracia, mais a escravidão surgia como contraponto indispensável, pois aos escravos eram reservadas tarefas como os trabalhos manuais.

O conceito de cidadão surgiu segundo Dallari (1984), durante a Revolução Francesa como uma demonstração de igualdade de todos, pois não havia mais nobres e plebeus e nem livres e escravos, apenas cidadãos. A noção de cidadania busca, portanto, expressar a igualdade dos homens no que se refere à vinculação jurídica a um determinado Estado. Como se vê o cidadão era dependente do Estado que estabelecia regras para a aquisição da cidadania, dizia quais eram os direitos dos cidadãos e as condições para usufruí-los fixando também, as hipóteses de sua perda. 
Assim, sendo a cidadania uma "invenção" do Estado, os direitos da pessoa poderiam ser reduzidos, bem como o cidadão poderia ser moldado e controlado pelo Estado.

Foi Marshall, no seu clássico Cidadania, classe social e status que analisou historicamente o desenvolvimento da noção de cidadania na Inglaterra. Para tal, dividiu o conceito de cidadania em três componentes: os direitos civis, os direitos políticos e os direitos sociais cada um deles correspondendo, respectivamente, às etapas do capitalismo entendidas como mercantilismo, liberalismo e monopolismo. Cronologicamente os direitos civis antecederam os direitos políticos e somente em meados do século $\mathrm{XX}$, os direitos sociais foram acrescentados ao conceito de cidadania. No entanto, o que parece que se processou nas três situações foi mais o direito de reivindicar tais direitos do que os seus atendimentos.

Ainda em seu ensaio, Marshall (1967) mostra que o desenvolvimento do conceito de cidadania deu-se simultaneamente com o desenvolvimento do capitalismo e este sendo um sistema que produz desigualdades sociais, e, por outro lado, o conceito de cidadania apregoasse a igualdade social, há obviamente, uma tensão permanente, uma "guerra entre o princípio de igualdade, implícito no conceito de cidadania e a desigualdade, inerente ao sistema capitalista”. Contudo, mesmo que no final do século XIX a cidadania pouco tivesse feito para minorar as desigualdades sociais, segundo Marshall não se pode negar que ela abriu caminho para a criação de políticas mais igualitárias no século XX.

Entretanto, o exercício dos direitos de cidadania parece que deu mais certo nos países integrados ao sistema do Welfare State, nas democracias modernas ocidentais. Mesmo assim, segundo Jaguaribe (1979), as medidas destinadas à equalização de oportunidades, tendo como objetivo reduzir substancialmente as desigualdades sociais, não foram confirmadas na prática. Nos países ditos periféricos, o processo de expansão da cidadania, como no caso brasileiro, difere tanto em termos de conquistas, quanto nos de exercício dos próprios direitos. É neste momento que identificamos a contradição que nos remete à necessidade de forjarmos os direitos com lutas que estabeleçam direitos e mecanismos que assegurem a sua aplicação e transfigurem-se na transformação da realidade social.

É necessário aqui, fazer uma breve conceituação sobre a divisão marshalliana acerca dos direitos numa análise didática para a melhor compreensão do que vem a ser cidadania.

Os direitos civis dizem respeito basicamente ao direito de se dispor do próprio corpo, quanto à locomoção, à segurança e à liberdade de expressão. A luta por esses direitos tem sido bastante intensa no mundo contemporâneo. Como exemplo, pode-se citar a experiência latinoamericana com as ditaduras militares que cercearam a liberdade de expressão ao trancafiarem e torturarem os opositores do pensar e do agir então dominantes. Vale ressaltar que a prática 
tirânica também ocorreu nos países socialistas do leste. A forma contemporânea de desrespeito a esses direitos pode ser exemplificada pelos esquadrões da morte, nos quais os policiais torturam e matam os considerados marginais num processo de "profilaxia social".

Dependentemente dos direitos civis estão os direitos políticos que dizem respeito à deliberação do homem sobre sua vida, ao direito de ter livre expressão de pensamento e prática política, religiosa e outras. Relacionam-se também, à convivência com outros homens em organismos de representação direta como os sindicatos, partidos, movimentos sociais, escolas, conselhos, associações de bairro ou indireta que é pela eleição governamental.

Por fim, têm-se os direitos sociais que se referem ao atendimento das necessidades humanas básicas como alimentação, habitação, saúde, educação, assistência social, transporte e outros.

Esses três direitos estão correlacionados e não podem ser entendidos separadamente, uma vez que para se realizarem efetivamente dependem de uma relação recíproca e de forças econômicas e políticas.

No entanto, ao enfocarmos os direitos sociais por serem o imperativo da justiça social e parte significativa do elenco de direitos humanos internacionalmente consagrados que postulam objetivos econômicos, sociais e culturais constituindo assim um importante marco da política social, ressaltamos o seu reconhecimento cada vez mais amplo como uma norma positiva que constitui em exigências fundamentais do homem, decorrentes de sua natureza social, que impõem à sociedade e ao Estado o dever de proporcionar a sua concretização.

Os direitos sociais no Brasil, como norma positiva, já estão consagrados na Carta Magna como direitos individuais ou princípios da ordem econômica e social.

No caso específico das pessoas portadoras de deficiência encontramos determinações constitucionais que podem ser chamadas de “discriminação positiva”, entendida como diferenciações legais que buscam equalizar direitos entre cidadãos diferentes. No caso em estudo referem-se à busca de incluir socialmente os indivíduos com deficiência, reconhecendo uma discriminação histórica por meio da reserva de mercado de trabalho no setor público e privado, garantia de acesso aos locais de uso público com especial referência aos transportes coletivos, garantia de benefícios sociais, como um salário de benefício para os que não puderem prover o próprio sustento, garantia de educação e de habilitação e reabilitação profissional, que se configuram como expressões de uma proteção especial por parte do Estado e da sociedade, além de outras. O quadro de inclusão social deste grupo de cidadãos se alterou positivamente nos últimos vinte anos, contudo, este reconhecimento formal demanda uma conscientização coletiva de sua dimensão como exigência fundamental da natureza 
humana e imperativo de justiça social. Ou seja, as pessoas precisam conhecer os seus direitos e principalmente saber como utilizá-los e a sociedade tem que estar preparada para esta convivência com a sua diversidade.

Nesta perspectiva, tornam-se relevantes como marcos de referência de uma política social centrada nas necessidades e aspirações das pessoas portadoras de deficiência, os direitos sociais nas áreas sócio-econômica entendida como direito ao trabalho, ao salário, à propriedade e à distribuição de renda; sociocultural referente aos serviços sociais públicos como educação, saúde, habitação, assistência social, transporte, cultura, lazer dentre outros; e por fim na área político-social, que refere-se ao direito à autonomia de organização, à participação e à cidadania social visando uma participação mais efetiva no processo democrático. Com isso, a validade do Estado de direito tem o seu alicerce no cidadão enquanto sujeito de uma política social que não deve só propiciar-lhe facilidades, mas garantir-lhe o direito à ampla informação e debate capazes de possibilitar uma visão crítica da realidade dentro de um amplo processo de mobilização e de participação.

Efetivamente foi por isso que as primeiras lutas do Movimento Nacional de Defesa dos direitos das Deficientes estiveram calcadas em dois pólos, pelo próprio simbolismo que representavam no sentido da aceitação e inclusão social dessas pessoas: direito à informação e acessibilidade. O homem é essencialmente um transeunte. É ao se movimentar e passar por lugares e culturas e conhecer pessoas e costumes que ele forma a sua própria singularidade e enriquece o mundo com a sua presença criativa. Negar ao Homem o direito de se comunicar e trocar experiências ao conhecer novas culturas, costumes e pessoas, e negar-lhe o direito de ir e vir, por exemplo, é contrariar a própria natureza. O homem é essencialmente um transeunte. É neste movimento que ele exerce a sua natureza.

\section{CAPÍTULO III}

\section{Os Brasileiros com Deficiência}

No Brasil, a realidade enfrentada pelas pessoas com deficiência que para cá vieram, aqui nasciam ou eram trazidas à força desde os tempos do descobrimento, não foi menos penosa que a dos humanos de outros lugares do Planeta.

Nos três primeiros séculos do nosso descobrimento a inexistência de dados específicos sobre esta população nos impede uma afirmação científica mais abalizada, mas dadas às condições sociais e culturais dos colonizadores, não é nem muito original imaginar que essas 
pessoas, quando faziam parte de famílias remediadas ou com condições econômicas simplesmente eram escondidas em propriedades familiares e raramente apareciam, sendo consideradas um "peso para a família”; quando pertencentes a grupos miseráveis, o pobre dos pobres e o desamparo grave.

Uma das primeiras referências de que se tem notícia sobre o problema das doenças e das incapacidades e limitações na história do Brasil está ligada a um episódio inusitado e cruel. O reconhecimento do problema advém de uma constatação dos senhores de escravos de que estaria havendo um abuso no uso da tortura e dos castigos com os cativos e que em decorrência disso muitos estavam ficando “imprestáveis" para o trabalho. Embora a Revolução Industrial ainda não houvesse chegado ao Brasil, a relação da deficiência com o modelo de produção sofria o seu primeiro impacto. Os cuidados com as populações escravizadas tiveram que ser repensados. Os problemas econômicos causados pela incidência de deficiência nas populações de escravos que eram submetidos a castigos e torturas e/ou acometidos de doenças infecciosas pelas inadequadas condições de moradia oferecidas, que traziam para a seara de discussões da elite governante o problema da deficiência exclusivamente pelos prejuízos econômicos que causava, mostra também a crueldade a que pode chegar o ser humano na exploração de seu semelhante. Embora a escravidão tenha sido abolida no Brasil no Século XIX, ainda hoje, lamentavelmente, na exploração nos desflorestamentos e queima de carvão e na colheita da cana-de-açúcar, por exemplo, não é raro encontrarmos trabalhadores em situação de escravidão, sendo traficados por "gatos" como simples objetos descartáveis. Paralelamente, a agressão ao meio-ambiente é brutal.

A primeira expressão positiva de que se tem notícia no Brasil de uma pessoa com deficiência, está traduzida na Obra de Antônio Francisco Lisboa, o “Aleijadinho” (1730 a 1814), que deixou um legado de esculturas em pedra sabão e madeira que fazem parte do acervo de Arte Sacra Brasileiro. A deficiência que acometeu o artista o obrigava a amarrar as ferramentas em suas mãos para poder lapidar a sua criação. É a singularidade humana se manifestando com força contra limitações e incapacidades.

Uma causa importante de incapacidades e limitações que acompanhou o Brasil dos Séculos XVI a XIX e que merecem destaque nesta narrativa são os problemas enfrentados pelos brasileiros com a medicina quase que inexistente por aqui na época. Era muito comum, por exemplo, como prática comum da incipiente medicina deste período, o instituto das amputações. É claro que era realizada em função de algum ferimento ou doença, mas gerava contingentes expressivos de amputados. 
No Império, a questão da deficiência começa a entrar na pauta de preocupações do Estado e da sociedade, e já em 29 de agosto de 1835 aparece a primeira proposição legal, de autoria do Deputado Cornélio Ferreira França dirigida especificamente às pessoas cegas e surdas-mudas, que determinava a criação na Capital do Império e nos principais lugares das províncias de uma classe para surdos-mudos e paras cegos que embora não tenha sido sancionada, indica a presença e a preocupação dos representantes do povo e do Estado com esta questão social. Sua existência foi trazida para o universo legislativo mostrando que a evolução da sociedade tenderia a aprofundar a preocupação social para com esses cidadãos.

Após a citada iniciativa legislativa só se encontrarão medidas de atenção a estas pessoas no contexto do Império aos meados do século XIX com a criação de organizações específicas para atender estes contingentes da população.

Antes disso, segundo Silva (1986), “as pessoas deficientes eram problema das famílias”. Se formos levar esta consideração ao pé da letra e questionarmos a visibilidade social dos pelo menos 20 (vinte) milhões de brasileiros portadores de algum tipo de deficiência da atualidade, com certeza, em grande medida, vamos concluir que eles, na verdade, ainda são muito mais problema das famílias do que propriamente uma questão social relevante sob a responsabilidade partilhada entre Estado, Sociedade e Família, como nos tempos referidos, pois a percepção quantitativa/visual que se tem desses indivíduos no cotidiano das cidades está muito aquém do que revelam as estatísticas, explicitando a exclusão social.

As organizações referidas anteriormente que foram criadas neste período são:

- O Imperial Instituto dos Meninos Cegos, criado por D. Pedro II em 17 de setembro de 1854, posteriormente transformado na República por Benjamim Constant, para Instituto Nacional dos Cegos, e hoje conhecido como Instituto Benjamim Constant - IBC, contando mais de 150 anos de prestação de serviços educacionais e de cursos de mobilidade para as pessoas cegas do Brasil;

- Em 1869, foram criados os Asilos dos Inválidos da Pátria, que acolhiam os soldados feridos e mutilados de guerra. Mesmo sendo considerados por muitos como um depósito de indigentes, estes locais representavam a presença deste problema social e a responsabilidade do Estado para com esses indivíduos. Como egressos de guerras de defesa e expansionistas, os "heróis" estavam a serviço do Império e, portanto, mereciam “abrigo”;

- Em 1887, foi criado o instituto dos Surdos-Mudos, conhecido hoje como Instituto Nacional de Educação de Surdos - INES. 
Após estas iniciativas governamentais poderemos encontrar uma série de iniciativas isoladas de atenção a estas pessoas em alguma situações com o apoio do Estado, mas principalmente oriundas nas iniciativas associativistas e de iniciativa dos familiares e profissionais diretamente envolvidos com a área, sendo que com especial ênfase às organizações de cegos, fruto dos desdobramentos dos trabalhos executados pelo Instituto Benjamim Constant e demais instituições criadas a partir do seu apoio e incentivo. As oportunidades educacionais ampliaram os horizontes das pessoas cegas, trazendo a possibilidade de superação das limitações e incapacidades.

Em função das possibilidades abertas pela educação proporcionada pelo IBC, as primeiras organizações de portadores de deficiência que surgem no Brasil, no início do século XX são as entidades ligadas às pessoas cegas, que desempenham um papel solitário, mas profícuo na defesa dos direitos e interesses das pessoas cegas na primeira metade do século XX. A defesa dos direitos das pessoas com deficiência entra na pauta da sociedade civil brasileira para não sair mais.

Surgem ainda instituições que atendem outros tipos de deficiência dispersas pelo Brasil, criadas a partir de iniciativas de familiares e técnicos ligados à área, e sempre com o caráter asilar e de separação. O foco que se voltava para a questão estava relacionado ao vetor cuidados e não para criar condições para a "independência” daquelas pessoas. Só com o surgimento dos grandes contingentes de deficientes físicos oriundos da primeira e segunda grandes guerras mundiais é que se adentrou pela trajetória de consideração desta questão social de forma mais expressiva, quando a Organização das Nações Unidas adotou o tema para estudo e consideração. Outra vez a responsabilidade do Estado foi cobrada de forma veemente, visto que aqueles homens eram oriundos das guerras de defesa de suas culturas e conceitos de liberdade. O problema da deficiência passa a fazer parte das preocupações dos organismos internacionais e a questão da possibilidade de participação social dessas pessoas passa a ser encarada como possível.

A partir da década de 50 são criadas as primeiras organizações nacionais, segundo consta no informativo - Mídia e Deficiência: Manual de Estilo CORDE (1996)

- Conselho Brasileiro para o Bem Estar dos Cegos - 1954;

- Federação Nacional das APAEs - 1962;

- Federação Nacional das Sociedades Pestalozzi - 1970; 
- Federação Brasileira de Excepcionais - 1974;

- Associação Nacional de Desporto para Deficientes - ANDE 1975.

Até este momento da história os interesses das pessoas com deficiência no Brasil vinham sendo representados quase que exclusivamente por seus familiares e pelos profissionais que trabalhavam na área, relegando as pessoas com deficiência a um papel subalterno no encaminhamento da defesa de seus direitos e interesses, atrasando e dificultando o amadurecimento do processo de formação para cidadania desses brasileiros.

No ano de 1979, no bojo de um movimento internacional de resgate dos direitos das pessoas com deficiência em escala mundial, deflagrado por ações da Organização das Nações Unidas - ONU que diagnosticaram a inexistência de políticas sociais voltadas para esses contingentes de seres humanos, como preparação para o Ano Internacional da Pessoa Deficiente que aconteceria em 1981, às pessoas portadoras de deficiência do Brasil começam a se tornar protagonistas de sua própria história, quando alguns grupos organizados e dirigidos por portadores de deficiência de vários tipos começam a se reunir para preparar o segmento para assumir o controle das ações que lhes diziam respeito.

O primeiro grande momento cívico deste incipiente movimento social que iniciava sua trajetória organizacional está consubstanciado no I Encontro Nacional de Entidades de Pessoas deficientes, realizado em Brasília no ano de 1980, que contou com a presença de cerca de 1.000 (mil) participantes, incluindo cegos, surdos, deficientes físicos, hansenianos e outros, vindos de todos os lugares do Brasil.

Este movimento organizado assumiu perante o Estado a representatividade nunca antes tida pelo segmento, e diversas ações de organização social, tanto no âmbito governamental quanto da sociedade civil, se seguiram a este momento:

- Foi aprovada a primeira Pauta de Lutas do Segmento;

- Foi criada a Coalizão Nacional de Entidades de Pessoas Deficientes, englobando todas as áreas de deficiência;

- Foi definida a Política a ser adota no Ano Internacional da Pessoa Deficiente;

- Como principal conquista identificamos que o movimento que surgia no cenário nacional era representado pelos próprios portadores de deficiência e não mais por especialistas. 
Posteriormente, o ano de 1984 foi também decisivo para a consolidação da organização das pessoas deficientes em nosso País, quando foram fundados:

- Federação Brasileira de Entidades de Cegos - FEBEC;

- A Organização Nacional de Entidades de Deficientes Físicos ONEDEF;

- A Federação Nacional de Educação e Integração dos surdos - FENEIS;

- O Movimento de Reintegração dos Hansenianos - MORHAN;

- Conselho Brasileiro de entidades de Pessoas deficientes, para reunir todas as entidades e substituir a Coalizão Nacional criada para a organização inicial do movimento no encontro de 1980.

Era a libertação das pessoas com deficiência no Brasil. Sob o Lema "Participação Plena e Igualdade” foram desfeitas as amarras da tutela até então imposta historicamente ao segmento.

É importante que destaquemos que neste momento histórico de afirmação das pessoas com deficiência no contexto social, frente à possibilidade de exercer a cidadania diretamente, surge também um sentimento de não compartilhamento dos rumos do movimento com as pessoas que anteriormente os estavam “tutelando”. Em certas situações surge até uma espécie de fundamentalismo, chegando ao ponto de se solicitar, nos momentos embrionários de nossas organizações, que as pessoas que não portavam deficiência se retirassem das plenárias nos momentos das votações.

Para que não paire dúvidas quanto à visão que entendemos mais adequada para esta relação, afirmamos que o elemento de identificação do compromisso não deve ser estabelecido pelo fato da pessoa portar ou não deficiência, e sim pelo seu compromisso com a causa, mesmo porque, muitos dos que foram considerados tutores antes da deflagração do processo de transformação das pessoas com deficiência de objetos para sujeitos de sua trajetória social e foram instados a sair dos auditórios nos momentos de afirmação destes indivíduos - e é perfeitamente compreensível do ponto de vista de quem esta se libertando que excessos tenham sido cometidos, foram exatamente os familiares e técnicos que não portavam deficiência mas entendiam que a tutela devia ser rompida. 
A estes pioneiros do nosso processo de emancipação, que nos incentivaram dentro dos centros de reabilitação e de nossos lares, por mais receio, cuidado e medo que tivessem sobre o que aconteceria quando tomássemos as rédeas de nossas vidas, rendo minhas homenagens! O receio do novo e do inexplorado não foi amarra suficiente para detê-los. A fé na possibilidade singular dos seres humanos é que norteou sua prática. Para mim, como nos tempos imemoriais, quando os homens cuidavam mutuamente uns dos outros porque sabiam instintivamente que dependiam uns dos outros para sobreviver, instintivamente esses pioneiros tiveram a capacidade de enxergar que o cuidado adequado para aqueles seres humanos passava a ser visto de um outro paradigma.

Por outro lado é importante frisar também um aspecto muito relevante e que também está relacionado à presença das pessoas sem deficiência em nossas organizações: Como a imagem das pessoas com deficiência tem um forte apelo social e possibilita a construção de imagens positivas para pessoas que buscam status social, com os conseqüentes benefícios inerentes à condição de filantropo no cenário comunitário, muitas pessoas se apropriaram da imagem das pessoas com deficiência, dificultando e atrasando o processo de emancipação que esta em curso.

Existem ainda as pessoas deficientes ou não que se apropriam desta imagem para auferir benefícios financeiros pessoais e "aplicar golpes na praça”, trazendo a nu a necessidade urgente de um processo efetivo de informação e diálogo com a sociedade para a efetivação da inclusão social destes indivíduos, que não permitam este tipo de exploração.

O papel das entidades e organizações de e para pessoas portadoras de deficiência tem que desempenhar o seu trabalho com firmeza de propósitos e a utilização da imagem simbólica das pessoas com deficiência, de grande apelo social, tem que ser usada com respeito.

Continuando nossa trajetória de organização, em 1985, foi fundada a Sociedade Brasileira dos Ostomizados - SOB, e em 1987 os paralisados cerebrais que até então eram representados pelas entidades de deficientes físicos ou mentais, fundaram sua própria entidade: A Associação de Paralisia Cerebral do Brasil - APCB.

Começa a consolidação do esporte adaptado para pessoas com deficiência no Brasil, que hoje são motivo de especial orgulho para nossa nação e tem contribuído enormemente como ferramenta para o aprofundamento do debate sobre a inclusão social do segmento.

Paralelamente ao movimento social e em função da pressão sofrida pelas instituições governamentais diretamente das pessoas com deficiência, agora organizadas, acontece o 
início da estruturação de uma política para o setor no interior da máquina estatal a partir das instituições de assistência social e de educação especial.

Seguindo a recomendação 89 do Programa de Ação Mundial para as Pessoas com Deficiência instituído pela ONU em 03 de dezembro de 1982, é criada, em 1987, por Decreto, a Coordenadoria Nacional para Integração da Pessoa Portadora de Deficiência - CORDE, posteriormente confirmada pela Lei n. ${ }^{0}$ 7.853/89, responsável pela coordenação superior dos assuntos subentendidos na Política Nacional para Integração Social das Pessoas com Deficiência e pela articulação inter-governamental e com as entidades da sociedade civil para efetiva aplicação da política. Esta Lei representa o principal marco legal nesta área e trata-se de uma espécie de Estatuto das pessoas portadoras de deficiência do Brasil, inserindo no arcabouço jurídico nacional os elementos legais necessários para a consolidação da cidadania desses brasileiros.

A deficiência como questão social passa definitivamente a fazer parte do cotidiano da Administração Pública.

A ação do movimento organizado das pessoas com deficiência, dentro do rico período de redemocratização do Brasil teve ainda um momento especial vivenciado na Assembléia Nacional Constituinte de 1986, desempenhando papel decisivo na defesa e garantia dos direitos das pessoas com deficiência, positivando na Carta Magna determinações históricas destinadas à atenção destes brasileiros, nos trabalhos realizados na Sub-Comissão das minorias.

Durante a década de 80 (oitenta) houve também a expansão do movimento em nível internacional com a ligação das entidades nacionais de pessoas deficientes com as representações internacionais respectivas.

No anos 90 (noventa) aconteceram também a regulamentação de determinações constitucionais que "pretendiam” - porque muitas ainda são mera expectativa - assegurar a presença das pessoas com deficiência no contexto social, das quais elencamos as mais importantes:

- Decreto 3.298/99, que dispõe sobre a Política Nacional para a Integração da Pessoa Portadora de Deficiência, consolida as normas de proteção;

- Lei 10.048/00, que dispõe sobre a prioridade no atendimento;

- Lei 10.098/00, que estabelece normas gerais e critérios para a promoção da acessibilidade das pessoas portadoras de deficiência ou com modalidade reduzida; 
- Decreto 5.296/04, que regulamenta as leis 10.048/00 e 10.098/00;

- Lei 8.112/90, que dispõe sobre o Regime Jurídico dos servidores públicos civis da União, das autarquias e das fundações públicas federais;

- Lei 8.213/91, que dispõe sobre os Planos de Benefícios da Previdência social;

- Lei 8.742/93, LOAS;

- Lei 9.394, LDB.

Colocadas estas condições de debate, aparece com uma nitidez cristalina que para que possamos dar um passo à frente na cidadania dos grupos mais vulneráveis socialmente, dentro da sociedade competitiva e globalizada em que atualmente vivemos, precisamos considerar diversos grupos que apresentam especial dificuldade em sobreviver dentro da ordem econômica imposta - onde apenas os mais fortes sobrevivem - pois apresentam maiores fragilidades pessoais e sociais e, por conseguinte, extrema adversidade para desempenhar mínimas funções que lhes garantam a satisfação de suas necessidades básicas.

Estão compreendidos neste grupo de cidadãos, só para se ter uma idéia, além dos portadores de deficiência, os idosos, as crianças e os jovens em situação de risco e vulnerabilidade, e os portadores de doenças crônicas e incuráveis que juntos representam, com certeza, expressiva parcela da população. Estes grupos, sem uma atenção especializada por parte dos governos, que viabilize de fato sua ascensão à qualidade de cidadãos, tendem a ser transformados em ingênuas presas de práticas políticas assistencialistas, que distam quilômetros dos ideais democráticos preconizados por nossa Constituição Federal. Impedidos de participar de forma plena do desenvolvimento da sociedade engrossam de forma indelével o grupo de deserdados da economia de mercado.

Nas discussões relacionadas às questões de gênero e raça, que se apresentam como especiais desafios a serem equacionados pela humanidade em futuro breve, têm merecido especial ênfase as ações que apontam para uma abordagem especializada, balizada pelos princípios de isonomia de oportunidades e defesa de direitos, - com intervenções afirmativas como a criação de quotas para ingresso no trabalho e ensino superior - que de uma vez por todas inclua todos os indivíduos no processo de desenvolvimento econômico, social e cultural.

Entretanto, os estados dos países em desenvolvimento, como via de regra e em função do estabelecimento do “estado mínimo” do liberalismo econômico, com produções de superávits primários cada vez maiores para saciar as demandas do mercado de capitais, em 
voga nos anos 90 (noventa), têm apresentado pouca ou nenhuma disposição política em alterar a realidade destes grupos sociais, compungindo-os a uma organização a partir da sociedade civil, conhecido como terceiro setor. É a sociedade assumindo atribuições que constitucionalmente estão definidas como obrigação estatal.

Esta irresponsabilidade histórica ter sido perpetrada neste período com relação à inclusão de todos no processo de distribuição das riquezas produzidas socialmente aliada à negligência na aplicação das políticas públicas que garantem direitos aos grupos fragilizados, acaba por criar uma legião de marginalizados sociais que, se observados com a profundidade necessária, deixa-nos bastante claro o quanto os Direitos Humanos são ainda relegados a um segundo plano pelos governos.

Esta realidade perdurou desde o início dos anos noventa até os primeiros anos do século XXI, quando as pessoas com deficiência perceberam que não podiam mais permanecer norteadas pelo fortalecimento institucional de suas próprias entidades, pois a magnitude desta questão social jamais poderá ser enfrentada a partir dos recursos humanos e financeiros da sociedade civil, e sim por meio das políticas públicas estruturadas adequadamente para atender a diversidade das pessoas. É deflagrado o processo de retorno às origens. $\mathrm{O}$ Movimento começa novamente a criar pautas nacionais e busca o aprofundamento da atuação política de suas entidades.

Neste Século, as organizações amadurecem o entendimento da necessidade de uma atuação conjunta e nacional para alcance de objetivos mais expressivos no sentido da efetivação e ampliação da cidadania desses brasileiros.

É o momento em que a diversidade social entra em voga e as organizações nacionais de defesa de direitos de grupos segregados ganham espaço no contexto da cidadania que se quer construir como legado para as gerações futuras. A escala global entra no cotidiano das pessoas com a ameaça planetária do "efeito estufa”. As redes de informação aproximam a realidade de lugares próximos ou distantes com a mesma velocidade, fazendo os humanos trocarem informações em tempo real cada vez mais intensamente. A perspectiva dos Direitos Humanos, embora muito atacada e desrespeitada dissemina-se e resiste como baluarte de um modelo ideal que se construiu mentalmente para a felicidade da humanidade. No próprio sistema ONU vamos encontrar com certeza enormes contradições quanto à acumulação e proteção do capital, entretanto, é também nele que a humanidade tem encontrado apoio para o encaminhamento das questões que a afligem. É nos fóruns internacionais que conseguimos dar visibilidade à opinião pública em escala mundial para questões pouco consideradas nas 
pautas dos Governos. É nesse sentido que a ONU me parece mais importante. É com a força da opinião das pessoas que fazemos e construímos o caráter político de nossas lutas.

Este processo crônico de negligência e exclusão deixou os segmentos socialmente mais vulneráveis à mercê de sua própria sorte, criando fenômenos de resistência no seio da sociedade civil que transplantaram as fronteiras dos países, desnudando problemas que pertencem, na verdade, a toda humanidade como conseqüência do modelo de desenvolvimento econômico e social implantado, e precisam ser equacionados em respeito aos próprios Direitos Humanos instituídos, sob pena de transformarmos estas determinações em cartas de intenção que permanecem muito longe do cotidiano das pessoas.

Para o enfrentamento adequado das questões sociais correlatas a estes segmentos da população, em função da timidez das iniciativas levadas a cabo pelos estados, os movimentos sociais adotaram como uma das suas estratégias apoiar-se no percurso de construção da luta pela defesa dos Direitos Humanos deflagrado pela Organização das Nações Unidas.

Num primeiro plano foram construídos os documentos indutores das políticas, produzidos sempre pelas populações diretamente envolvidas, com o apoio e participação da Organização das Nações Unidas - ONU, por intermédio das suas Agências de Fomento.

Os documentos produzidos em parceria com os segmentos organizados da sociedade civil em escala global balizaram as primeiras iniciativas de alteração da realidade identificada, com contínuo e constantemente aprimoramento de pesquisas e estudos, que resultam em Convenções Internacionais que explicitam os mecanismos que devem ser seguidos pelos estados partes para superação das dificuldades sociais crônicas da humanidade e ainda hoje representam fonte de inspiração para os movimentos sociais. É claro que os países precisam ratificar as determinações dispostas nos textos da ONU para que sejam acolhidas no ordenamento jurídico, mas é também perfeitamente razoável perceber que estes documentos acabam por configurarem-se com instrumentos de luta para as populações.

É também insistentemente destacado nesses documentos que o foco especial sob os segmentos vulneráveis socialmente exige como diretriz maior a conduzir estes trabalhos à audição aos grupos diretamente envolvidos, sinalizando de forma veemente o caminho que os países membros devem trilhar, que serve de instrumento de constrangimento contra estados autoritários que insistem em aceitar o novo momento da sociedade civil mundial.

Assuntos como o respeito aos Direitos Humanos; a defesa da mulher contra a violência e a discriminação; integração racial; respeito à religiosidade de todos os povos; defesa de crianças e jovens contra todo o tipo de violência, discriminação, negligência, opressão e omissão; igualdade de oportunidades para as pessoas portadoras de deficiência; proteção 
integral aos portadores de doenças crônicas e incuráveis; respeito ao idoso e defesa de sua condição de genitor da própria humanidade; defesa das populações indígenas; exploração sustentável do meio-ambiente, e outros assuntos de importância global, são o dia-a-dia do trabalho das Nações Unidas e suas Agências. A importância que se dá a estes temas está relacionada com o fato de que ultrapassam as fronteiras nacionais e estão diretamente vinculadas ao futuro que desejamos para a civilização.

Assim, para uma abordagem pertinente e eficaz a ação governamental tem que estar subordinada e identificada com os reais interesses da população, bem como traduzida para ela na priorização das medidas governamentais, consubstanciadas, segundo preceitos do modelo democrático nos programas partidários, que precisam ser melhor observados pelos eleitores, pois este é o momento em que fazemos as escolhas para o futuro de nossa vida, cidade, estado, nação e planeta. É neste contexto que as pessoas com deficiência começam, mesmo que timidamente, a buscar seu espaço dentro das instâncias decisórias da sociedade. A educação política é imprescindível como mediadora das relações sociais e um forte instrumento para a alteração de realidades sociais adversas.

Podemos identificar facilmente a partir das ações administrativas e políticas de um governo, a diferença entre o governo comprometido com o povo e as lutas sociais justas, que busca o equilíbrio e o planejamento na administração pública, e o que governa sob a batuta de interesses espúrios e imediatistas, que de maneira inexorável logo vêm à tona sob a forma de escândalos e malversações.

No campo político, ações que atingem frontalmente as determinações da Carta dos Direitos Humanos, os direitos constitucionais e atentam contra princípios democráticos, explicitam a demagogia embutida nos discursos vazios e assistencialistas de pretensos salvadores da Pátria.

No campo administrativo, porém, com exceção dos grupos organizados, nem sempre a população está atenta ou consegue depreender nas ardilosas manobras levadas a efeito pelo governo, retrocesso na luta por igualdade plena em nossa sociedade, pois é refém deste próprio governo através de suas políticas de submissão.

Feita esta reflexão, é imperioso que estejamos sempre vigilantes para, no mínimo, identificar medidas equivocadas efetivadas pelos governos nos dois campos, esclarecendo a população sobre as conseqüências de tais atos, relacionados a conquistas históricas dos segmentos acima mencionados, que significam, na prática, retrocesso nos seus processos individuais e coletivos de conquista de cidadania plena. A cidadania precisa ser vigilante. 
Apenas para citarmos alguns exemplos que iluminam o pensamento humano, sem prejuízo de outros tantos que poderiam, do mesmo modo conjugarem esforços para um melhor desempenho da função pública, elencamos abaixo os seguintes títulos:

- A plataforma Beijing 95 - Um Instrumento de Ação para as Mulheres -;

- O Estatuto da Criança e do Adolescente, além de diversas recomendações, tratados e convenções internacionais referentes a crianças e jovens;

- A Convenção da ONU sobre a Eliminação de todas as Formas de Discriminação Racial (1966) - ratificada pelo Brasil - ;

- O Programa de Ação Mundial para as Pessoas com Deficiência, aprovado pela Assembléia Geral das Nações Unidas, pela resolução 37/52, de 03 de dezembro de 1982;

- O documento intitulado Subsídios para Planos de Ação dos Governos Federal e Estaduais na Área de Atenção ao Portador de Deficiência, editado pela Coordenadoria Nacional para Integração da Pessoa Portadora de Deficiência;

- recomendação 190 - recomendação sobre a proibição das piores formas de trabalho infantil e ação imediata para sua eliminação, da organização internacional do trabalho

Todos os documentos sugerem aos governos as diretrizes para o desencadeamento das ações de inclusão social dos grupos mais vulneráveis socialmente e são apresentados como anexos deste trabalho de monografia.

Estes exemplos nos permitem depreender que o modelo institucional proposto para o equacionamento das questões relacionadas aos grupos abrangidos nesta exposição, ou outros que temporária ou permanentemente apresentem fragilidade social, está diretamente relacionado à priorização política que se deseja dispensar a estes temas.

Estabelecem, também, como ponto de partida para o desenvolvimento de ações eficazes que visem o alcance de níveis de qualidade de vida apropriados para estes grupos, a criação de mecanismos institucionais de planejamento, de articulação, de assessoramento e de defesa de direitos destes coletivos sociais, localizados dentro da estrutura estatal com acesso direto a mais alta instância de deliberação governamental, com o intuito de deixar claro para toda a administração pública sobre a priorização política e administrativa que os assuntos relacionados à cidadania e aos Direitos Humanos merecem. Sem este compromisso do 
mandatário responsável pela condução do interesse público, não conseguimos avançar com a efetividade e a perenidade que as questões sociais exigem.

Ao mesmo tempo, o modelo institucional proposto guardado as devidas proporções e situações específicas dos grupos envolvidos, podem, por analogia, ser aplicados aos demais segmentos vulneráveis de nossa população. Estes coletivos de cidadãos, quando ouvidos em fóruns específicos, requerem acima de tudo e a semelhança dos demais submetidos a processos de exclusão social, a priorização política e administrativa que estes temas exigem e participação plena na discussão e elaboração/aplicação dos programas, projetos, medidas e ações governamentais que lhes digam respeito, assegurando que funcionem de forma perene, já que são caracterizadas como iniciativas de Estado e não apenas de Governo, e consubstanciadas em mandamentos constitucionais.

Sem adotar as medidas necessárias do ponto de vista administrativo e principalmente conferir prioridade política e administrativa, que descronifiquem situações sociais históricas de exclusão social, condenamos definitivamente expressivos contingentes de nosso povo a uma cidadania de segunda classe.

\section{A Cidadania no Brasil}

É visível hoje, na sociedade brasileira, a discussão em torno dos direitos do cidadão apesar da questão não ser nova, pois se sabe que a noção de cidadania está ligada, historicamente, à luta pela emancipação do indivíduo no processo de formação e consolidação do Estado-Nação. Trata-se de um velho tema, cuja origem, está referenciada nas teorias do Direito Natural.

Na história brasileira, não se pode negar que a existência de pressão, por parte dos trabalhadores na luta pela conquista dos direitos de cidadania, é anterior a 1930. Mas também não se pode perder de vista que a trajetória pela conquista desse status está marcada pela antecipação do Estado em agir tutelarmente, incorporando gradativamente as reivindicações das classes populares, como uma espécie de lenitivo dado a conta gotas, para que o processo de emancipação plena acontecesse da forma mais lenta possível, sem grandes alterações no statu quo.

A questão da ampliação da noção de cidadania sempre esteve presente na história brasileira, contudo, sua trajetória e prática têm sido permeadas por avanços e retrocessos.

É verdade, também, que os preceitos de igualdade preconizados por esta concepção estão ainda distantes de serem alcançados. Na história brasileira, como coloca Weffort (1981), 
não haveria exagero em dizer que a desigualdade social tem vencido a "guerra", pois ao contrário da hipótese de Marshall, a cidadania como instituição em desenvolvimento, que asseguraria o progresso da igualdade contra a desigualdade social, tem-se uma cidadania que espelha e reforça a exclusão. Neste contexto, a temática está presente nas discussões intelectuais e acadêmicas nas quais se evoca o seu significado libertário.

Há também a emergência dos movimentos sociais, que se rearticulam e passam a exigir o cumprimento dos direitos conquistados ao longo da história, assim como a ampliação do conceito de cidadania. Esses grupos reclamam, pois, do caráter tutelar do Estado em relação aos dominados; questionam a ineficácia e as deficiências do aparelho estatal no que diz respeito ao atendimento dos direitos fundamentais do cidadão. Além disso reivindicam direitos que ultrapassam o quadro capitalista, tais como a luta pelo solo urbano, pela propriedade da terra e por direitos diferenciados para grupos historicamente excluídos do processo de desenvolvimento sócio-econômico-cultural dentre outros.

Como já foi dito na apresentação, não faremos um levantamento exaustivo sobre o desenvolvimento da cidadania no Brasil e sim reconstruiremos um quadro geral a partir de 1930 com a origem do Estado tutelar acompanhado de suas características de " unidade nacional " e com objetivos de organizar uma sociedade vista como dispersa e desarticulada.

Nesta perspectiva, esse Estado populista e autoritário, sobretudo no Estado Novo, tratou de construir um Estado Nacional avesso a qualquer regionalismo e privatismo característicos das velhas oligarquias. Os direitos sociais reivindicados pelos trabalhadores ao longo desse período eram atendidos como doações paternais, com características de outorga, uma vez que a contestação das camadas dominadas refluiu e o movimento operário entrou em longa depressão. Com isso o Estado adquiriu uma feição democrático-igualitária.

Na verdade, a legislação getuliana tinha subjacente a tarefa de domesticar os conflitos, tutelando-os em dois sentidos básicos: primeiro, não permitindo que o movimento operário se organizasse de forma autônoma e, segundo, reduzindo o espaço civil público para as questões "não relevantes", ou seja, fora do projeto unitário de dominação.

Neste contexto, a política corporativa afeta não só a organização sindical, mas o conjunto das instituições democráticas, obstaculizando a conquista da cidadania pelos trabalhadores, tanto que no período de 1937 a 1945, com a ditadura do Estado Novo, há um fechamento do sistema político brasileiro decorrente da suspensão do sistema eleitoral.

Após 1930, os direitos de cidadania são construídos em outras bases. Integram a "comunidade cívica" aqueles que estão diretamente ligados ao processo produtivo. Santos (1979) propõe para se entender a política econômico-social desse período, o conceito de 
cidadania regulada cujas raízes encontram-se não em um código de valores políticos, mas num sistema de estratificação ocupacional definido como norma legal. Portanto, são cidadãos aqueles trabalhadores que se encontram engajados na produção e que desempenham "ocupações reconhecidas e definidas por lei". Nesse caso, o processo de cidadania é estratificado e sua extensão se dá mediante a regulamentação de novas profissões e/ou ocupações em primeiro lugar, e mediante ampliação do escopo dos direitos associados a essas profissões, antes que por expansão dos direitos inerentes ao conceito de membro da comunidade. Neste contexto as pessoas com deficiência eram atingidas frontalmente, visto que havia pouca ou nenhuma possibilidade de ocupação.

Como se vê, a cidadania estava embutida na profissão e os direitos dos cidadãos restringiam-se aos direitos do lugar que ocupava no processo produtivo, tal como reconhecido por lei. Portanto, aqueles trabalhadores cuja ocupação a lei desconhecia eram considerados pré-cidadãos, bem como aqueles cujas ocupações não eram reguladas por lei. Nesta ótica, eram pré-cidadãos os trabalhadores rurais que não tomavam parte ativa no processo de produção, os brasileiros que não tinham registro de nascimento e os analfabetos. Fica claro também, embora nem referido, que os deficientes estavam neste contingente.

Segundo Viana (1983), a nação se "estataliza" e sendo uma criatura do Estado, não tem identidade própria, uma vez que não se organiza, é organizada como um corpo de funcionários a serviço do ideal da expansão da acumulação tentando impor a constituição de uma comunidade ideológica com base na colaboração entre as classes com objetivo de grandeza nacional. Sua análise corresponde à afirmativa de Santos quando coloca que a política social em vez da eqüidade cede lugar às exigências da acumulação.

Se na República Oligárquica a legislação social era limitada aos setores vitais da economia agroexportadora, no Brasil pós-30, a ordem corporativa implantada não elevou os trabalhadores à cidadania, muito ao contrário, o processo de constituição e organização das classes populares iniciado na Primeira República foi interrompido. Além do caráter desorganizativo das classes, a ordem corporativa dava acesso ao cidadão de usufruírem das vantagens e dos benefícios concretos mediante os direitos dos cidadãos decorrentes dos direitos das profissões.

A cidadania regulada também estava presente na legislação previdenciária analisada por Santos (1979). À mão-de-obra mais qualificada e mais escassa deveria corresponder salários mais elevados. Desta forma, os benefícios previdenciários eram concedidos aos cidadãos por via da regulamentação profissional em função do nível de renda na medida em que quem mais podia contribuir, maiores e melhores benefícios poderia demandar. No entanto, o sistema 
previdenciário não era extensivo aos trabalhadores rurais aos quais só foram concedidos na década de 60 e posteriormente em 1978 com o FUNRURAL .

No chamado período de redemocratização, que se estendeu de 1945 a 1964, permitiu-se a existência legal, embora por curto prazo, de um partido operário. O Estado brasileiro pautou-se então, pelo princípio da cidadania regulada e da submissão da justiça ao princípio de maximização da eficiência do mercado.

Assim sendo, pode-se afirmar que nenhum governo no pós-45 tomou qualquer iniciativa mais consistente e sistemática no que diz respeito à alteração dos princípios da cidadania regulada e à obediência ao mercado econômico. Esse período começou como terminou: com a regulamentação das profissões, com a carteira de trabalho e com o sindicalismo corporativista, que eram os parâmetros para a definição dos direitos de cidadania.

O golpe militar de 1964, ao violar a Constituição de 1946, elaborada por uma Assembléia Nacional Constituinte, começou por ser um ato político de destituição de um presidente da República. Através dos atos institucionais, o governo procurou consolidar a sua própria ordem jurídico-política, dizendo-se representante do povo para em seu nome exercer o poder constituinte.

Com o Ato Institucional número 5 o Presidente da República além de poder decretar o recesso do Congresso Nacional, das Assembléias Legislativas e das Câmaras de Vereadores, dando maiores poderes para o Executivo legislar; suspendeu os direitos políticos dos cidadãos e cassou mandatos eletivos federais, estaduais e municipais. Assim, calaram-se os partidos políticos e, evidentemente, o Legislativo esvaziou o seu poder e a capacidade de representar os interesses e as reivindicações dos grupos e classes sociais. Esse poder de representação foi transformado em foro de debates de problemas, nem sempre relevantes.

O Poder Judiciário foi subordinado ao Poder Executivo sendo conferido ao poder instituído ampla liberdade de ação à espionagem, à intimidação, à prisão, ao seqüestro e à tortura a todos os oponentes do regime. Com isso, foi afastado da vida pública um número expressivo de pessoas, entre elas políticos, lideranças sindicais, intelectuais, e muitas delas pelo simples fato de expressarem livremente seu pensamento, inclusive no meio estudantil. Foram criados os esquadrões da morte que eliminaram uma parcela expressiva, embora desconhecida, de pessoas delinqüentes ou não.

O regime militar caracterizou-se pelo distanciamento da sociedade civil. Esta sociedade passou a ser considerada perigosa, sobretudo para os interesses do bloco no poder. Não obstante, passou a ser tutelada e vigiada. 
Os problemas sociais tais como a prostituição, o menor abandonado e a delinqüência juvenil foram definidos como práticas criminosas. O aparelho de poder, diante da gravidade desses problemas, criou uma gama de instituições que além de abrirem espaço para discussão e divulgação destinavam-se a escamotear tanto a violência quanto à brutalidade com que eram tratados os problemas. Praticamente, o Estado interferiu em todos os aspectos da vida social, econômica, política, cultural e educacional.

A violação da ordem democrática em 1964 colocou em recesso a dimensão política da cidadania brasileira. A sociedade voltou a um estágio quase pré-organizado, político e socialmente, na medida em que os partidos políticos não participavam efetivamente da administração do governo e os sindicatos eram mantidos sob severa vigilância ou "aparelhados“ com pelegos, bem como as entidades estudantis e demais instrumentos de organização social.

Não se pode nem falar em cidadania na sociedade brasileira após 1964, quando muito se fala em cidadania administrativa, tolerada, outorgada e regulada, uma vez que não havia povo, mas uma massa de ignorantes. Era repassada à sociedade a ideologia de que a população brasileira era composta por pessoas despreparadas que não sabiam lutar pelos seus direitos.

Entretanto, as políticas sociais eram repassadas aos trabalhadores não como um direito social, mas como um "benefício" que o governo estava prestando à sociedade. A característica peculiar deste período para o enfrentamento das manifestações da questão social - além da repressão - foi que os direitos sociais foram organizados de forma a atender um duplo objetivo: o favorecimento de acumulação do capital e a subordinação aos preceitos da ideologia de Segurança Nacional.

Neste contexto, surgem os "benefícios indiretos" financiados pela classe trabalhadora através da poupança forçada, que abrindo mão de parte do consumo imediato, usufruía dos bens indiretos na forma de políticas sociais como: saúde, educação, habitação e outros.

O milagre brasileiro ergueu-se sobre a miséria das massas trabalhadoras. Além do caráter repressivo do Estado, viabilizaram-se outros mecanismos para alcançar o desenvolvimento; assim sendo, aumentaram a exploração da força de trabalho, ampliando a jornada de trabalho, institucionalizando as horas extras, intensificando o ritmo de trabalho e foram criados outros mecanismos com o objetivo explícito de aumentar a produtividade. Neste contexto o padrão de vida das classes trabalhadoras deteriorou-se e a inclusão laboral das pessoas com deficiência em escala compatível com o percentual de presença dela na sociedade era apenas um sonho. 
Em contrapartida, aparecem na cena política brasileira os movimentos de bairros fortalecidos e reorganizados. Esse reaparecimento dos movimentos populares de base, entre eles o "novo sindicalismo" e os movimentos populares aparecem na medida em que uma multiplicidade de problemas avilta as condições de vida das massas populares. Nestes espaços começam a aparecer os primeiros líderes do Movimento Nacional de Defesa dos direitos das Pessoas Deficientes.

A partir de 1976 esses movimentos multiplicam-se e eclodem nos mais distantes bairros da periferia, notadamente nos grandes centros urbanos e com diferentes formas de organização, que resultaram na capacidade de articulação dos moradores na luta pelo direito à cidadania. Na prática, esses movimentos reclamavam pela expansão dos direitos de cidadania tanto no nível dos direitos sociais quanto dos direitos políticos, ao reivindicarem maior participação na vida pública e a diversidade que compõe o mosaico social é explicitada.

Desta forma, os movimentos de bairro afirmam seu direito à água, luz, esgoto, assistência médica; luta-se pelo direito da posse da terra, regularizando os loteamentos clandestinos. As mulheres reiteram seu direito à igualdade; os movimentos negros contra a discriminação racial; as mães lutam pelo direito à creche; os índios pelas suas terras; o movimento sindical pelo direito à greve e todos lutavam pelo direito à proteção contra a violência; as pessoas portadoras trazem para a pauta social as reivindicações das pessoas portadoras de deficiência consubstanciada na emenda constitucional n. ${ }^{\circ}$ 12/79, que determinava já no tempo da Ditadura Militar a criação de um organismo estatal para cuidar da coordenação dos assuntos e ações afetos à área, conhecida como “Emenda Thales Ramalho”.

Neste universo de luta por redemocratização os portadores de deficiência começam a trilhar um novo caminho, estabelecendo como pauta primeira de sua luta o protagonismo nas ações que lhes dizem respeito.

A discussão em torno dos direitos de cidadania que se operou no interior dos movimentos populares foi um amplo processo de revisão e redefinição do espaço da cidadania. Nesse sentido, parece não ser exatamente a noção de cidadania "abstrata", "pura" que constitui as reivindicações dos trabalhadores, pois as lutas são prioritariamente por necessidades básicas como transporte, educação, saúde, habitação, acessibilidade, ou seja, por melhores condições de vida além de reclamarem por direitos de expressão social e de política. Processa-se, pois, a construção coletiva de uma nova cidadania.

O "novo sindicalismo", por exemplo, desencadeado por trabalhadores do setor de ponta da economia nacional transcenderam nas suas lutas as questões corporativas, pois ao lado da questão do aumento salarial, estabilidade no emprego, limite de quarenta horas semanais de 
trabalho e o direito de representação sindical na empresa, os metalúrgicos colocaram na pauta de suas reivindicações os direitos sociais e políticos que alcançaram um conjunto bastante amplo das classes populares. Desta forma, os direitos sociais aparecem como condição de possibilidade dos direitos políticos da mesma forma que as conquistas políticas são percebidas como condição de conquista social.

Por sua vez, os trabalhadores rurais se rearticulam se fortalecem e passam a reorganizarse politicamente, pois suas condições de vida são brutais, uma vez que vivenciam não só a exploração no campo, mas também uma situação de exclusão dos direitos fundamentais, como o de propriedade, os trabalhistas e até de certos direitos fundamentais como o direito de ir e vir, determinado pela pobreza que os atinge.

Os índios lutam pela sua autodeterminação, preservação da sua cultura e de suas terras. Estes querem ser sujeitos, e viverem sem ameaças constantes do extermínio.

A emergência de novos sujeitos históricos no cenário brasileiro, de novas formas de organizações e de pressão concretizam-se e exigem os direitos fundamentais de cidadania. A exigência destes direitos aparece na medida em que a população, sobretudo nas zonas periféricas, percebe, a partir da sua condição de vida, a condição de excluída e de cidadãos pela metade.

A luta desses movimentos tem, como se pode verificar, uma dimensão ideológica e política. Mesmo sendo as suas reivindicações por necessidades básicas mais elementares, o imediatismo das reivindicações corporativas, visto que põem em questão as suas condições de cidadãos pela metade e não cidadãos. Parece, portanto, ser nesse sentido que a cidadania se redefine.

No contexto da chamada "Nova República", não há ainda espaço para o exercício efetivo da cidadania, pois se convive com as instituições e legislações oriundas não só da ditadura militar, mas também do Estado Novo como, por exemplo, a legislação sindical que permanece praticamente intacta, a legislação antigreve, assim como a proibição da sindicalização dos funcionários públicos. Apesar de ter sido devolvida parte da cidadania aos brasileiros privados durante vinte anos de eleger seus governantes, a Emenda Constitucional N. ${ }^{\circ}$ 26, promulgada em 26 de novembro de 1985, estabeleceu que o Congresso a ser eleito em novembro de 1986 elaboraria a nova Constituição. No entanto, essa nova Carta não teve a efetiva participação popular que foi relegada quando se nomeou a Comissão Provisória de Assuntos Constitucionais para a tarefa de elaborar o projeto da nova Constituição, entretanto, os grupos sociais exerceram uma pressão permanente que resultou em alguns avanços inegáveis. No caso das pessoas alvo deste estudo, foram positivados direitos que explicitam 
um contrato social de acolhimento e assimilação. A sua efetivação depende do processo de mediação estabelecido pela correlação de forças estabelecidas na sociedade. Quanto maior a organização social, maior a capacidade de pressão.

Contemporaneamente, a discussão em torno da cidadania reaviva-se com a Constituição de 1988, no entanto, a batalha dos trabalhadores e dos grupos mais vulneráveis socialmente no debate constituinte através dos representantes e da pressão popular é essencialmente pela construção de uma democracia dentro da ordem e do que ela possa proporcionar ao criar condições materiais e políticas que possam elevar a qualidade de vida dos cidadãos brasileiros.

No entanto, é interessante ressaltar que em consonância com a idéia de cidadania regulada proposta por Santos (1979), Carvalho (2002) assinala que no Brasil surgiram em primeiro lugar os direitos sociais no momento da supressão dos direitos políticos, sendo que o direito ao voto emergiu num momento autoritário, sem falar que muitos dos direitos civis estão fora do alcance da população.

De acordo com Teixeira (1994), há no Brasil uma cidadania invertida que consiste na inclusão social pelo assistencialismo e pelo clientelismo que é uma forma de negação da cidadania. Isso para Demo (1996) é uma forma de cidadania menor, uma vez que gera uma situação de pobreza política devido à falta de participação e de controle democrático.

Como foi brevemente discutido, o desenvolvimento da cidadania no Brasil enquanto garantia dos direitos insere-se num processo de acumulação capitalista dependente, desigual e que subordina a população despolitizada aos interesses dos grupos dominantes.

Percebe-se hoje, formas de filantropia privada que tendem, devido a má gestão no controle democrático da política de assistência social e à falta histórica de recursos financeiros para sua implementação, relegar essa política para a iniciativa privada. Com essa privatização e sem o controle democrático, a razão pública fica desacreditada quanto às possibilidades de elaboração e execução dos projetos coletivos havendo assim, um retrocesso no processo de avanço da cidadania. O que segundo Ribeiro (2000), acaba colocando a sociedade contra o social. Uma vez que o Estado é dispensado de garantir os direitos, despolitiza a noção de cidadania que passa de uma noção social para a individual dos direitos a fim de garantir a estabilidade monetária das atividades financeiras. Com isso, há a emergência de uma solidariedade fragmentada.

É neste contexto que as relações sociais ficam extremamente adversas para os portadores de deficiência; é nesta situação que ele fica refém de atenções assistencialistas que o afastam ainda mais da cidadania. A própria exclusão social os afasta da possibilidade de 
compreender o que é cidadania, e quando seus direitos são atendidos de alguma forma pelas políticas públicas, ainda assim se sentem gratos aos indivíduos que os atenderam; não entendem a dimensão pública dos serviços que receberam, dos quais, na verdade, são anteriormente credores. A exclusão social multiplica-se velozmente num circulo vicioso abjeto, que acaba por jogar esses indivíduos ao Limbo.

Portanto, o processo de cidadania no Brasil precisa elevar a discussão para um patamar de paradigmas que estabeleçam os elementos capazes de mediar todas as necessidades apresentadas pela diversidade de grupos que compõem o mosaico social, sem o que estaremos sempre rodando em círculos, num processo de avança e retrocede, sem conseguir consolidar a cidadania que a riqueza produzida socialmente no Brasil permite. 


\section{CONSIDERAÇÕES FINAIS}

O processo de desenvolvimento capitalista brasileiro é marcado por profundas desigualdades que são, ao mesmo tempo econômicas, sociais e políticas. Referem-se às condições de renda, consumo, de acesso à informação, de propriedade e de poder. Parcelas expressivas da sociedade brasileira reconhecem algumas dessas desigualdades reforçando também, que a maioria dos segmentos sociais não têm acesso através do mercado, onde as pessoas com deficiência são atingidas implacavelmente, a determinados bens e serviços considerados essenciais, cabendo então ao Estado assumir algumas provisões.

No entanto, para avançarmos na discussão acerca da política social como um direito, é preciso clarificar o conceito de política pública uma vez que a assistência social, como toda e qualquer política social, é um capítulo da política pública. A política pública não é uma atividade exclusiva do Estado, pois a palavra pública, associada à política, não é sinônimo de ação estatal ou de ingerência governamental, mas identifica-se com a res publica - coisa de todos, do povo. É por isso que se afigura como um espaço de atuação tanto do Estado quanto da sociedade que passa a ter representatividade, poder de decidir e condições de exercer o controle sobre a sua própria reprodução e sobre os atos e decisões do governo e do mercado.

Essa noção de política pública difere-se da visão funcionalista em que a política pública deveria estar sob a direção estatal e, portanto, representando a alocação autoritária de decisões pensadas e postas em prática pelo Estado na sociedade. Em outros termos, para essa visão, cabe ao Estado criar e conduzir as políticas públicas, enquanto que a sociedade é o terreno pacífico ou amorfo onde estas políticas são operacionalizadas. Ao rejeitarmos essa concepção funcionalista acerca das políticas públicas queremos ressaltar que o Estado e os governantes não são os personagens principais e exclusivos para a elaboração desse processo, uma vez que a sociedade também deve exercer um papel ativo e decisivo na definição e desenvolvimento das políticas públicas que a protejam e lhes são devidas como direitos.

No âmbito estatal, a política social configura-se como um tipo de intervenção do Estado frente aos problemas decorrentes das desigualdades sociais sendo que as respostas aos casos extremos, constituem as intervenções identificadas como de assistência social, que expressam uma forma de regulação e de reprodução social da população excluída do acesso aos direitos sociais, onde as pessoas com deficiência são atingidas, como já nos referimos, de forma implacável.

No entanto, a assistência social parece que não tem decorrido do direito de cidadania, pois se constitui em formas dispersas e fragmentadas de auxílios temporários ou emergências 
a segmentos sociais. A cidadania implica não só na universalização dos direitos formais, mas também na garantia efetiva do acesso a bens e serviços essenciais sem barreiras e discriminações, aos indivíduos de um mesmo país. Isso acaba gerando uma convivência dialética na sociedade capitalista brasileira, uma vez que os princípios universais de cidadania na prestação de serviços sociais são fragmentados e seletivos baseados em princípios clientelistas e assistencialistas.

No Brasil, a Constituição Federal de 1988, que foi elaborada no meio de umas das mais profundas crises econômicas e sociais, além de ter significado o fim da transição apontou para a consolidação da democracia participativa ao formalizar e atribuir legalmente ao Estado, a responsabilidade sobre a garantia dos direitos sociais presentes no complexo da Seguridade Social.

O sistema de Seguridade Social é entendido como um conjunto integrado de ações de iniciativa do poder público e da sociedade, destinadas a assegurar os diretos relativos à saúde, à previdência e à assistência social. É composto por um conjunto de três políticas com características diferenciadas, no entanto, convém esclarecer brevemente a competência de cada uma. A política de saúde orienta-se pelos princípios da universalidade, da gratuidade, da redistributividade e da descentralização. A política previdenciária pauta-se pelos preceitos de gestão centralizada e de direitos contributivos. Por sua vez, a política de assistência social guia-se pelos princípios da seletividade, da gratuidade e da redistributividade, além da gestão centralizada para os benefícios de prestação continuada e da descentralizada para os programas, os projetos e serviços.

Com este novo ordenamento, a assistência social, que foi regulamentada pela lei número 8.742, de 07 de dezembro de 1993, denominada Lei Orgânica da Assistência Social (LOAS). Esta Política aponta, num primeiro plano, como exigência para sua consolidação, a luta da sociedade civil em efetivá-la como política pública operando o princípio da igualdade de direitos, promovendo a eqüidade para reduzir as desigualdades sociais e o acesso para todos que dela necessitarem. Isso requer o dever do Estado para assumir a sua responsabilidade no enfrentamento das manifestações da questão social.

O financiamento dessa política é uma das mais significativas expressões desse enfrentamento, cujos mecanismos inscrevem-se no Capítulo V, artigos 27 a 30 da Lei Orgânica de Assistência Social (LOAS). O Conselho e o Fundo de Assistência Social constituem mecanismos essenciais na destinação, na orientação e no controle do seu financiamento. Para tal controle, é fundamental ressaltar o acompanhamento feito pelo Ministério Público que como instituição atua na defesa e na garantia da cidadania. No caso 
das pessoas portadoras de deficiência física, no Distrito Federal o Ministério Público atua por meio da Promotoria de Justiça de Defesa do Idoso e do Portador de Deficiência (PRODIDE), defendendo e providenciando as medidas cabíveis quanto aos direitos relacionados à eliminação de barreiras arquitetônicas, garantia de reserva de mercado de trabalho, atendimento educacional especializado, ações contra maus tratos e abandono e mau atendimento nos estabelecimentos de saúde, no sistema previdenciário e na área de assistência social.

É interessante ressaltar que a assistência social direcionada aos "cidadãos desamparados”, independentemente da contribuição à Seguridade Social, tem objetivos delimitados tais como proteção à família, à maternidade, à infância, à adolescência e à velhice assim como amparo às crianças e aos adolescentes carentes, promoção para a integração ao mercado de trabalho, habilitação e reabilitação da pessoa portadora de deficiência garantindolhe, assim como ao idoso sem condição de autodeterminação e provisão das necessidades mínimas, um salário mínimo mensal.

O caráter ambíguo e impreciso do que vem a ser assistência social, pois ao mesmo tempo que tem o status de direito social e portanto universal, seleciona os beneficiários ao destinar-se a segmentos específicos considerados "necessitados”. Percebe-se então, a sua concepção seletiva - a quem necessita, e focalizada - particularizada em seguimentos determinados, seguindo a lógica de buscar a eqüidade via a seletividade.

É bem verdade que a luta por garantia de direitos também faz parte da Política de Assistência Social e não tem um corte seletivo, entretanto este viés ainda é pouco explorado.

Ao propor uma definição para os critérios de delimitação de cobertura, Demo (1989) defende a focalização em determinados grupos, previamente definidos, a fim de universalizar a assistência para os mesmos. Com base nessa proposição, argumenta que a assistência deve constituir um direito permanente e, portanto ininterrupto aos segmentos que não possuem condições de auto-sustentação tais como os inválidos, os deficientes, os idosos e as crianças em situação de risco e abandono.

Por outro lado propõe baseado no critério de vulnerabilidade extrema, a assistência destinada aos grupos que por razões de calamidade pública, encontram-se com as oportunidades de sobrevivência reduzidas. No entanto, essa situação não deve perpetuar-se como uma ação contínua a sistemática, pois há um risco de caracterização da pobreza como um fenômeno natural e de reprodução social da miséria.

A satisfação de necessidades sociais no campo da assistência social não se resume à distribuição de bens materiais voltada para a dimensão biológica do cidadão. A assistência 
social também deve estar associada à oferta de recursos intangíveis, voltados para as dimensões cognitiva e emocional do cidadão, oferta que muitas vezes incide no campo dos direitos individuais de autonomia. É onde entra o processo de organização social e defesa de direitos.

É interessante ressaltar que a política social assume um caráter dialético, encontrando-se no momento em recuo principalmente nos países que no passado instituíram elevados padrões de proteção bem acima dos mínimos universalmente reconhecidos. A justificativa apresentada pelos governantes é que não se está a por em causa os direitos sociais mínimos, mas tão só os direitos mais elevados que foram instituídos em conjunturas mais favoráveis e que portanto são reversíveis, mesmo significando uma visível quebra de bem-estar adquirido. Desse modo, a retração das políticas sociais ganha justificação política com o fundamento da reversibilidade dos direitos sociais, uma vez que há uma dificuldade de conseguir um comprometimento maior do Estado com os níveis de proteção social ajustados à sua capacidade econômica e à dificuldade de fiscalizar a realização efetiva desse compromisso.

Uma das principais características ideológicas do pensamento econômico neoliberal é a afirmação da liberdade de mercado como a melhor forma de consecução do bem-estar coletivo. Para os neoliberais, as desigualdades são produtos da utilização diferenciada da capacidade de cada cidadão, que usufrui de sua liberdade natural para decidir e encaminhar o que melhor para si. Por essa ótica, a desigualdade é tida como um produto da opção e desejo do próprio indivíduo e não uma injustiça social, uma vez que “todos têm oportunidades” para desenvolverem suas capacidades.

No entanto no Brasil, na concepção universalista dos direitos sociais, contra a qual as tendências neoliberais se insurgem, houve uma defasagem entre os princípios igualitários da lei e a realidade das desigualdades e exclusões produzidas pelas mudanças estruturais contemporâneas.

A Constituição de 1988, denominada Constituição-Cidadã, mesmo com as dificuldades enfrentadas para garantirmos no texto constitucional os direitos das pessoas deficientes teve na sua formulação importantes princípios democráticos e de garantia e ampliação dos direitos capazes de estruturar uma sociedade igualitária, com oportunidades para todos. E é dentro dessa perspectiva de ampliação da cidadania que conseguimos compreender a inclusão social dos brasileiros portadores de deficiência. 


\section{REFERÊNCIAS BIBLIOGRÁFICAS}

ABREU, Marina Maciel. “A relação entre o Estado e a sociedade civil: a questão dos conselhos de direitos e a participação do Serviço Social”, Revista Serviço Social e Movimento Social. São Luís; Edufma, n. 1, 1999.

ARAÚJO, Luiz Alberto David - A proteção constitucional das pessoas portadoras de deficiência. 2. ed, Brasília, CORDE, 1996.

BICUDO, Hélio. Os direitos civis no Brasil, existem?. São Paulo, Brasiliense,1982.

BOBBIO, N. A Era dos Direitos. Rio de Janeiro: Campus, 1992.

BOSCHETTI, Ivanete. Assistência Social no Brasil: um direito entre originalidade e conservadorismo. Brasília: GESST/SER/UNB, 2001.

CARVALHO, José Murilo de. Cidadania no Brasil: O longo caminho. Rio de Janeiro, Civilização Brasileira,2002.

CESARINO JR, A. F. Direito Social. São Paulo, USP, 1980.

DALlARI, Dalmo de Abreu. Ser cidadão . Lua Nova. São Paulo, Brasiliense,vol.1, n. 2,jul/set/1984.

DEMO, P. Assistência e emancipação - Discutindo estratégias de trabalho com menores de rua. Brasília, IPLAN/CEC, jul./1989.

DEMO, P. Charme da exclusão social. Campinas, Autores Associados, 1998.

DEMO, P. Pobreza política. Campinas, Autores Associados, 1996.

DICIONÁRIO de Ciências Sociais. São Paulo: Ed. FGV, 1973.

DRAIBE, Sônia. “As políticas sociais brasileiras: diagnósticos e perspectivas”. Para a década de 90: prioridades e perspectivas de Políticas Públicas, IPEA/IPLAN, Brasília, março 1990. P. $1-67$.

ENGELS, Friedrich . A dialética da natureza. São Paulo: Paz e Terra, 1979

FALEIROS, Vicente de Paula. O que é Política Social. São Paulo: Brasiliense, 1997.

FARIA, J. E. (org.). Direitos humanos, direitos sociais e justiça. São Paulo: Malheiros, 1998. HELLER, Agnes. Além da justiça. Rio de Janeiro: Civilização Brasileira, 1998.

INSTITUTO BRASILEIRO DE GEOGRAFIA E ESTATÍSTICA - IBGE - Censo Demográfico realizado em 2002.

IAMAMOTO, Marilda Villela; CARVALHO, Raul de. Relações Sociais e Serviço Social no Brasil: esboço de uma interpretação histórica-metodológica. 11 ed. São Paulo: Cortez, 1996. JAGUARIBE, H. Introdução do desenvolvimento social. Rio de Janeiro, Paz e Terra,1979. MARSHALL, T. H. Cidadania, Classe Social e Status. Rio de Janeiro: Zahar, 1967. 
MARX, K.; ENGELS, F. A ideologia alemã. São Paulo: Martins Fontes, 1974.

MARX, K. Para a crítica da economia política. São Paulo: Ed. Nova Cultural, 1996. p. 24-

54. ( Coleção os Pensadores: Marx)

MARX, K O Método da Economia Política Contribuição à Crítica da Economia Política. In: FERNANDES, F. (Org.). Marx/Engels - História, SP, Ática, 1989, Coleção Grandes Cientistas Sociais, No. 36.

Programa de Ação Mundial para as Pessoas com Deficiência - Organização das Nações Unidas - promulgado na Assembléia Geral da Organização em 03 de dezembro de 1982, pela resolução 37/52.

PEREIRA, P.A.P. A Assistência Social na perspectiva dos direitos: crítica aos padrões dominantes de proteção aos pobres do Brasil. Brasília: Thesaurus, 1996.

PEREIRA, P.A.P. Necessidades Humanas Básicas: subsídios a crítica dos mínimos sociais. São Paulo. Cortez, 2000.

RAICHELIS, Raquel. Esfera pública e conselhos de assistência social: caminho da construção democrática. São Paulo: Cortez, 1998.

REVISTA SER SOCIAL N. 5, “Trabalho e Cidadania”, Revista do Programa de Pós Graduação em Política Social, Departamento de Serviço Social da UnB. Brasília, julho a dezembro de 1999.

REVISTA SER SOCIAL N. 8, “Direitos Humanos e Políticas Sociais”, Revista do Programa de Pós Graduação em Política Social, Departamento de Serviço Social da UnB. Brasília, janeiro a junho de 2001.

RIBEIRO, Renato Janine. A sociedade contra o social: o alto custo da vida pública no Brasil. São Paulo: Companhia das Letras, 2000.

RUIZ, J. A. Metodologia Científica: guia para eficiência no estudo. 4 ed. São Paulo: Ed. Atlas. 1996.

SANTOS, Boaventura de Sousa. Por uma concepção multicultural de direitos humanos. Lua Nova, São Paulo, n. 39, 1997.

SANTOS, Wanderley Guilherme dos. Cidadania e Justiça: a política social na ordem brasileira. Rio de Janeiro: Campus, 1979.

SILVA, Otto Marques da. A Epopéia Ignorada - A Pessoa Deficiente na História do Mundo de Ontem e de Hoje - São Paulo - CEDAS, 1986.

TEIXEIRA, S.F. Estado sem cidadãos. Seguridade Social na América Latina. Rio de Janeiro, Fiocruz,1994.

TELLES, Vera da Silva. Direitos sociais: afinal do que se trata? Belo Horizonte: Ed. UFMG, 1999. 
VIANA, Luís Werneck. O problema da cidadania na hora de transição democrática. Dados, Rio de Janeiro, Campus, vol. 26, n.3, 1983.

VIEIRA, Liszt. Cidadania e Globalização. Rio de Janeiro: Record, 1997.

VIEIRA, Liszt. Os Argonautas da cidadania: A sociedade civil na globalização. Rio de Janeiro, Record, 2001.

WEFFORT. F.C. et alli. Direito, Cidadania e Participação. São Paulo, Tao, 1981.

INSTITUTO BRASILEIRO DE DEFESA DOS DIREITOS DA PESSOA COM DEFICIÊNCIA - IBDD - Sem Limites - Inclusão de Portadores de Deficiência no Mercado de Trabalho - Rio de Janeiro: SESC, 2002.

INSTITUTO BRASILEIRO DE DEFESA DOS DIREITOS DA PESSOA COM DEFICIÊNCIA - IBDD - Responsabilidade Social e Diversidade: Deficiência, Trabalho e Exclusão - Rio de Janeiro: BNDES, 2004. 


\begin{abstract}
$\underline{\text { ANEXOS }}$
PLATAFORMA DE AÇÃO DE BEIJING - MECANISMOS INSTITUCIONAIS PARA IGUALDADE
\end{abstract}

A reunião de Beijing terminou com uma declaração e um instrumento de ação aprovados pelas delegações governamentais, com um movimento de mulheres visível a nível internacional, animado por sonhos e utopias diversas para o futuro e, sobretudo, com a satisfação de Ter dado um salto qualitativo na luta pela igualdade para as mulheres, que se traduz, simultaneamente, em um passo a frente nos processos de democratização.

O tema da discriminação de gênero transcendeu o movimento que o originou $e$ penetrou nas instituições oficiais e nos espaços públicos, mobilizando a atenção de políticos, jornalistas e empresários, entre outros.

Quais são então as tarefas que nos competem?

Em primeiro lugar, difundir o sentido do processo que nos levou a Beijing e os conteúdos da Plataforma de Ação. Ela foi possível graças à mobilização de expressões organizadas de mulheres que, a partir de seus espaços autônomos, relacionaram-se com diferentes atores sociais e com os governos. A capacidade de comunicar as demandas, bem como a articulação das matérias em debate com temas de interesse geral - Democracia, Desenvolvimento e Paz, - tornaram possível o intercâmbio que teve lugar na IV Conferência.

Em segundo lugar, convocar as diferentes organizações de mulheres a se apropriarem - segundo sua lógica e interpretação particular - dos direitos objetivos e medidas contidas na Plataforma e dos novos temas que emergiram na agenda do Fórum Mundial de ONGs.

Em terceiro lugar, afirmar o direito à cidadania plena das mulheres, pressionando para que sejam criados mecanismos de negociação, de consulta e de opinião que assegurem a participação dos grupos de mulheres nos processos de priorização $e$ implementação da Plataforma de Ação. Contudo, é preciso insistir em que o âmbito institucional oficial é uma referência para o movimento, mas não seu lugar natural, que está situado na sociedade civil e nos espaços públicos autônomos. (conselhos etc.)

Em quarto lugar, aumentar a capacidade de reflexão do movimento, sua compreensão sobre o cenário mundial e regional onde se dão suas lutas, e a identificação dos novos atores e interesses que se mobilizam em torno da não discriminação. O movimento 
deve situar-se simultaneamente em diversos espaços no nível internacional, regional $e$ nacional que, provavelmente, são regidos por lógicas diferentes. ( grifo nosso)

Finalmente, um último e importante desafio consiste em apropriar-se da Plataforma para fazer avançar a posição das mulheres, ficando em alerta para identificar os novos temas e demandas que sejam por elas apresentadas nos diferentes espaços, por mais distanciados que estejam dos âmbitos mais públicos e oficiais.

A participação, a interlocução e a negociação só serão possíveis em igualdade de condições, com um movimento visível, forte e legítimo, que propicie uma nova lógica de relação com os governos responsáveis pela implementação da Plataforma.

Em quase todos os países foram criados mecanismos nacionais para o progresso das mulheres - Tratam-se de Conselho, Secretarias, coordenações e ministérios da mulher e políticas e/ou programas em favor da igualdade -. Seu objetivo é a coordenação de políticas dos governos. Sua tarefa é incorporar a perspectiva de igualdade entre os gêneros em todas as esferas da política e do governo.

Para que funcionem com eficácia é necessário:

1 - Estabelecer instâncias nos mais altos níveis de governo;

2 - Agilizar o planejamento descentralizado para conseguir a participação das ONGs e organizações comunitárias desde a base;

3 - Dispor de suficientes recursos orçamentários e recursos humanos capacitados;

4 - Definir procedimentos para que esses mecanismos tenham influência na formação de todas as políticas governamentais.

Os Governos se comprometem a:

1 - Facilitar a formulação e aplicação de políticas governamentais sobre igualdade entre mulheres e homens;

2 - Criar ou fortalecer mecanismos nacionais e órgãos governamentais;

3 - Integrar perspectiva de gênero em legislações políticas, programas e projetos estatais.

4 - Preparar e divulgar dados e informações que se destinam ao planejamento $e$ avaliação discriminados por sexo. 
Conforme o artigo 86 do Estatuto da Criança e do Adolescente, "a política de atendimento far-se-á por um conjunto articulado de ações governamentais, da União, dos estados, do Distrito Federal e dos municípios”. (grifo nosso)

Como se depreende dessa formulação, dois princípios presidem à estruturação da política de atendimento: o principio da hierarquia e o princípio da complementaridade. Pelo primeiro, se vai do município à União, passando pelos estados e pelo Distrito Federal. Pelo segundo, se estabelece a concatenação entre esforços do Estado e da sociedade.

Mais do que justapor instâncias e níveis de gestão, a política de atendimento inscrita no Estatuto busca conferir organicidade ao conjunto de ações, governamentais ou não, em favor da infância e da juventude por meio de uma reconfiguração das diversas modalidades de intervenção presentes na sociedade e, principalmente, no ramo social do Estado brasileiro.

Isso ocorre no momento em que as intervenções são hierarquizadas com base no critério da abrangência das quatro modalidades de atuação previstas nas linhas definidoras do perfil da política de atendimento.
a) políticas sociais básicas;
b) política de assistência social;
c) política de proteção especial;
d) política de garantias.

(Este pequeno extrato retirado da obra - Trabalho Infantil, de Antônio Gomes da Costa, da Organização Internacional do Trabalho/OIT - ratifica o pensamento sobre a priorização que os governos devem dispensar à política de atenção às crianças e jovens $e$ estabelece claramente o caráter de complementaridade entre as políticas sociais públicas).

Eixos para uma Política Nacional:

O Fórum Nacional vem discutindo e aprimorando uma proposta que contribui para a elaboração de uma Política Nacional de prevenção e erradicação do trabalho infantil que enfrente esse desafio.

Depois de ouvidos diversos setores da sociedade, os integrantes do Fórum Nacional definiram os seis eixos fundamentais que deveriam orientar a construção da proposta de Política Nacional.

Esses eixos são os seguintes: criação de uma base de dados confiável sobre o trabalho infantil no país; melhoria da renda familiar e desenvolvimento local integrado $e$ sustentável; fiscalização e controle efetivos para a prevenção do trabalho infantil; garantia 
de escola de qualidade para todas as crianças e adolescentes; melhoria de articulação institucional; e, por último, aperfeiçoamento da legislação de proteção à criança e ao adolescente, para que se possa contribuir para a sua efetiva aplicação.(grifo nosso)

Fixados os eixos para a elaboração de uma minuta de proposta, o Fórum Nacional pretende agora aprofundar a discussão do assunto junto ao governo federal, estados, prefeituras, Congresso Nacional e segmentos representativos da sociedade, solicitando a colaboração de todos para que a Política Nacional de Prevenção e Erradicação do Trabalho infantil comece a ganhar corpo e possa vigorar a partir do ano 2000.

\section{RECOMENDAÇÃO 190 \\ RECOMENDAÇÃO SOBRE A PROIBIÇÃO DAS PIORES FORMAS DE TRABALHO INFANTIL E AÇÃO IMEDIATA PARA SUA ELIMINAÇÃO ORGANIZAÇÃO INTERNACIONAL DO TRABALHO}

Plano de Ação - Item III/ Aplicação:

1. Os Estados Membros devem Ter e manter dados estatísticos atualizados e informação detalhada sobre a natureza e o alcance do trabalho infantil, de modo que sirvam para estabelecer as prioridades de ação

2. nacional dirigida à erradicação do trabalho infantil, e em particular a proibição e eliminação de suas piores formas em caráter de urgência.

8. Os Estados Membros das Nações Unidas, consultando previamente as organizações de empregadores e de trabalhadores, devem criar mecanismos apropriados para vigiar a aplicação das disposições nacionais sobre proibição e eliminação das piores formas de trabalho infantil.

(citamos apenas os dois dispositivos que tratam do tema mecanismos institucionais, sem prejuízo das demais disposições daquele fundamental tratado internacional)

CONVENÇÃO DA ONU SOBRE A ELIMINAÇÃO DE TODAS AS FORMAS DE DISCRIMINAÇÃO RACIAL - 1966

Os Estados Partes condenam a discriminação racial e comprometem-se a adotar uma política de eliminação da discriminação racial em todas as suas formas e de promoção 
de entendimento entre todas as raças. Para esse fim, cada Estado Parte compromete-se a não efetuar ato ou prática de discriminação racial contra pessoas, grupos de pessoas ou instituições; a não encorajar, defender ou apoiar a discriminação racial praticada por uma pessoa ou organização qualquer, a tomar as medidas eficazes, a fim de rever as políticas governamentais nacionais e locais e para modificar, ab-rogar ou anular qualquer disposição regulamentar que tenha como objetivo criar a discriminação ou perpetrá-la onde já existir; a adotar as medidas legislativas, proibir e por fim à discriminação racial praticada por pessoas, por grupos ou por organizações; favorecer, quando for o caso, as organizações e movimentos multirraciais e outros próprios a eliminar as barreiras entre as raças e a desencorajar o que tende a fortalecer a divisão racial. Os Estados Partes comprometem-se a proibir e a eliminar a discriminação racial em todas as suas formas e a garantir o direito de cada um à igualdade perante a Lei sem distinção de raça, de cor ou de origem nacional ou étnica.

\section{PROPOSTAS PARA A EXECUÇÃO DO PROGRAMA DE AÇÃO MUNDIAL REFERENTE ÀS PESSOAS DEFICIENTES}

Os objetivos do Programa de Ação Mundial referente às Pessoas Deficientes consistem em promover medidas eficazes para a prevenção da deficiência, para a reabilitação e, para se alcançar os objetivos de "igualdade" e "participação plena" das pessoas deficientes. Ao aplicar o Programa de Ação Mundial, deve-se dar a devida atenção à situação especial dos países em desenvolvimento e, em especial, à dos menos adiantados. A enormidade da tarefa de melhorar as condições de vida de toda a população e a falta geral de recursos fazem com que seja mais difícil alcançar os objetivos do Programa de Ação Mundial. Ao mesmo tempo, deve-se reconhecer que a aplicação deste Programa contribuirá para o processo de desenvolvimento, graças à mobilização de todos os recursos humanos e à participação plena de toda a população. Embora alguns países já tenham iniciado ou realizado algumas da medidas recomendadas no Programa, é necessário fazer mais. Isso se aplica também aos países que têm um nível de vida elevado.

Como a situação das pessoas deficientes está estreitamente relacionada com o desenvolvimento geral a nível nacional, a solução dos seus problemas, nos países em desenvolvimento, depende, em grande medida, da criação de condições internacionais adequadas para um desenvolvimento sócio-económico mais rápido nesses países. Por conseguinte, o estabelecimento de uma nova ordem econômica internacional é de 
importância direta para se atingir os objetivos do Programa. É fundamental que o fluxo de recursos para os países em desenvolvimento seja aumentado de forma considerável, de acordo com o convencionado na Estratégia Geral de Desenvolvimento para a Terceira Década das Nações Unidas para o Desenvolvimento.

A consecução destes objetivos exigirá uma estratégia mundial pluri-setorial e multidisciplinar, para a aplicação combinada e coordenada de políticas e medidas visando a igualdade de oportunidades para as pessoas portadoras de deficiência, serviços eficazes de reabilitação e medidas de prevenção.

As pessoas portadoras de deficiência e suas organizações deverão ser consultadas no desenvolvimento posterior do Programa de Ação Mundial e durante a sua execução. Para isso, deve-se fazer todo o possível para fomentar a criação de organizações de pessoas portadoras de deficiência, a nível nacional, regional e internacional. A sua singular experiência, derivada das suas vivências, pode trazer importantes contribuições para o planejamento de programas e serviços destinados às pessoas portadoras de deficiência. Ao expressarem a sua opinião sobre tais assuntos, apresentarem pontos de vista amplamente representativos de todos os seus interesses. A sua repercussão nas atitudes públicas justifica o fato de que sejam consultadas e, enquanto força que propicia mudanças, têm uma influência apreciável para converter as questões referentes à deficiência numa questão prioritária. As próprias pessoas portadoras de deficiência deverão exercer uma influência substantiva para decidir a eficácia de políticas, programas e serviços concebidos em seu benefício. Esforços especiais devem ser envidados para se fazer com que as pessoas portadoras de deficiência mental tenham participação no processo.

\section{Medidas Nacionais:}

O Programa de Ação Mundial foi concebido para todas as nações. Não obstante, o prazo de execução e a seleção dos pontos a serem realizados prioritariamente variarão de país para país, segundo a situação existente e as limitações dos seus recursos, o grau de desenvolvimento econômico, as tradições culturais e a capacidade de formular e executar as medidas previstas no Programa.

Cabe aos governos nacionais a responsabilidade última da aplicação da medidas recomendadas neste capítulo. Não obstante, em virtude das diferenças institucionais entre as regiões dentro de cada país, as autoridades locais serão chamadas a aplicar as medidas nacionais contidas no Programa de Ação Mundial. (grifo nosso). 
Os Estados Membros devem iniciar com urgência os programas nacionais a longo prazo para atingirem os objetivos do Programa de Ação Mundial; esses programas devem ser parte integrante da política global de desenvolvimento sócio-econômico da nação.

Os assuntos referentes às pessoas portadoras de deficiência devem ser tratados dentro do contexto geral apropriado, e não separadamente. Cada ministérios ou organismo do setor público ou privado que esteja encarregado de um determinado aspecto ou atue dentro dele, deve assumir a responsabilidade pelos assuntos referentes às pessoas portadoras de deficiência compreendidos na sua esfera de competência. Os governos devem estabelecer um ponto de observação (por exemplo: uma comissão, comitê ou outro órgão de âmbito nacional) para examinar ou vigiar as atividades dos diversos ministérios, de outros órgão públicos e das organizações não-governamentais relacionadas com o Programa de Ação Mundial. De qualquer mecanismo que se crie devem participar todas as partes interessadas, inclusive as organizações de pessoas portadoras de deficiência. Esse órgão deve ter acesso às instância decisórias de mais alto nível (grifo nosso).

Do segundo documento acima citado, no item IV, consta:

\section{RECOMENDAÇÕES DE NATUREZA INSTITUCIONAL}

Manutenção e fortalecimento de um órgão na esfera pública federal, de preferência diretamente vinculado à Presidência da República, com dotação orçamentária própria, destinado a coordenar, elaborar, implementar e monitorar as políticas públicas para pessoa portadora de deficiência, apoiado por um colegiado de caráter deliberativo representativo da sociedade civil e de organizações governamentais.

Provimento desse órgão coordenador com estrutura organizacional técnica e orçamentária compatível com os suas funções (Lei 7.853/93 Art. 10 e 12);

Manutenção, no Ministério da Educação e do Desporto, da Secretaria de Educação Especial e do Departamento de Desporto para Pessoa Portadora de Deficiência.

Manutenção e implementação dos serviços oferecidos pelos Centros de Reabilitação Profissional do Instituto Nacional de Seguridade Social - INSS.

Manutenção dos programas supletivos de prevenção, habilitação, reabilitação e geração de emprego e renda, desenvolvidos pelo Ministério do Bem-Estar Social e seus 
órgãos vinculados (Fundação Legião Brasileira de Assistência - LBA e Fundação Centro Brasileiro para Infância e Adolescência - CBIA).

Manutenção e implementação dos programas desenvolvidos pelo CBIA de atenção a criança e adolescentes portadores de deficiência em situação de risco pessoal e social.

Criação, no Ministério do Trabalho, de Núcleo para implementação de programas de formação profissional e de inserção de pessoas portadoras de deficiência no mercado de trabalho.

Incentivo à criação de setor específico de defesa do portador de deficiência nos ministérios públicos federais e estaduais.

Apoio técnico e financeiro a iniciativas de atenção a pessoa portadora de deficiência, desenvolvidas por instituições sem fins lucrativos.

Incentivo à criação, nos estados e municípios, de órgão coordenador de ações relativas a pessoa portadora de deficiência nas respectivas instâncias.

Participação de organizações de e para portadores deficiência nos Conselhos federal, estaduais e municipais nas áreas da Saúde, Educação, Assistência Social, Criança e Adolescente, idoso e outros.

Incorporação, nos inquéritos censitários e pesquisas amostrais, de informações sobre pessoa portadora de deficiência para subsidiar políticas e planos de governo destinados a esse segmento populacional.

Criação de fundo específico para a manutenção de ações relativas à assistência da pessoa portadora de deficiência. 